ANL-8125

LMFBR Fuels and Materials Engineering and Development $(\mathrm{UC}-79 \mathrm{~b})$

\author{
ARGONNE NATIONAL LABORATORY \\ 9700 South Cass Avenue \\ Argonne, Illinols 60439
}

\title{
FUEL-ASSEMBLY MATERIALS SIMULATION \\ PROGRAM: STATUS REPORT
}

by

J. T. A. Roberts, J. J. Weins,

C. A. Youngdahl, F. L. Yaggee,

P.S. Maiya, and J. E. Spruiell*

Materials Science Division

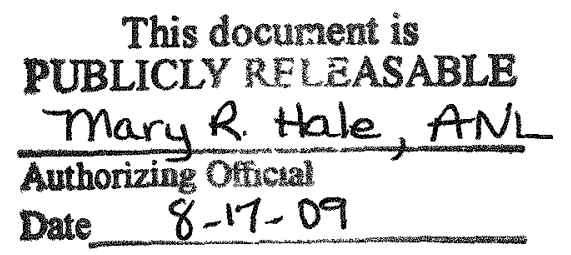

October 1974

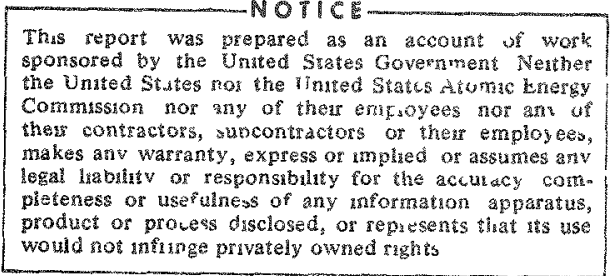

*University of Tennessee

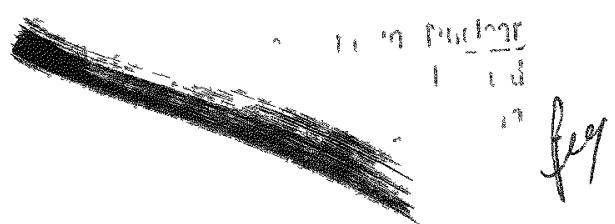




\section{DISCLAIMER}

This report was prepared as an account of work sponsored by an agency of the United States Government. Neither the United States Government nor any agency Thereof, nor any of their employees, makes any warranty, express or implied, or assumes any legal liability or responsibility for the accuracy, completeness, or usefulness of any information, apparatus, product, or process disclosed, or represents that its use would not infringe privately owned rights. Reference herein to any specific commercial product, process, or service by trade name, trademark, manufacturer, or otherwise does not necessarily constitute or imply its endorsement, recommendation, or favoring by the United States Government or any agency thereof. The views and opinions of authors expressed herein do not necessarily state or reflect those of the United States Government or any agency thereof. 


\section{DISCLAIMER}

Portions of this document may be illegible in electronic image products. Images are produced from the best available original document. 
-

• 
TABLE OF CONTENTS

$\underline{\text { Page }}$

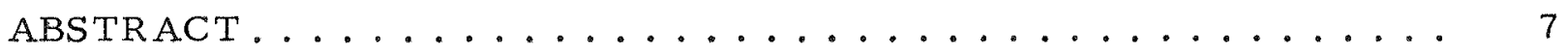

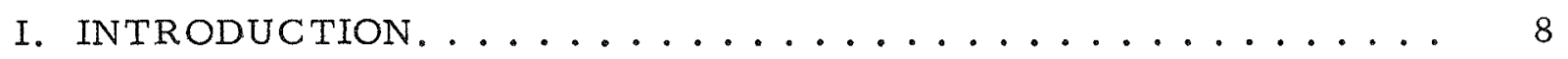

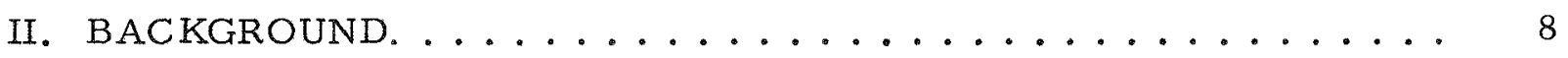

A. Local-subassembly Malfunctions .................. 9

B. Whole-subassembly LOF Accidents ............... 10

III. ASSESSMENT OF SLSF EXPERIMENTAL REQUIREMENTS. . . . 10

IV. CLADDING-DUCT MATERIALS SIMULATION . . . . . . . . 12

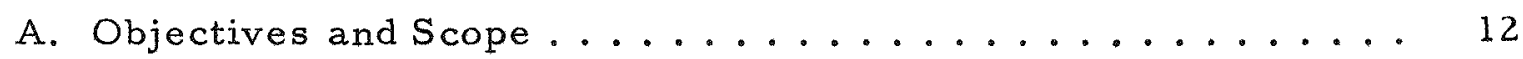

B. Experimental Procedure and Results .............. 14

1. Thermomechanical Treatments of Type 316 Stainless

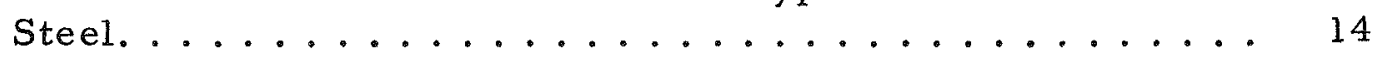

2. Thermochemical Treatments of Type 316 Stainless Steel.. 15

3. Transient Tube-burst Tests on Simulated Cladding . . . . . 16

4. Cha racterization of Simulated Ducts............ 22

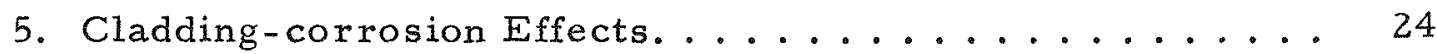

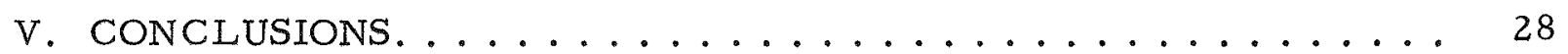

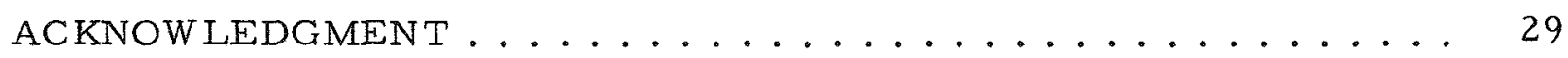

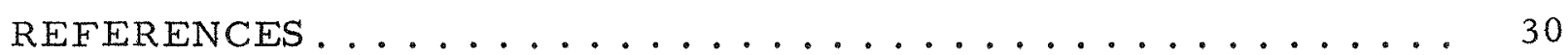




\section{LIST OF FIGURES}

No.

Title

Page

1. Predicted Plenum Pressure for FTR Fuel Elements........ 10

2. Effect of Irradiation on the Strain of $20 \%$ Cold-worked Type 316 Stainless Steel Fuel Cladding under EOL Loading Conditions during Temperature Transients Simulating LOF Accidents . . . .

3. Predicted Fission Gas Retained in Fuel as a Function of Fuel-

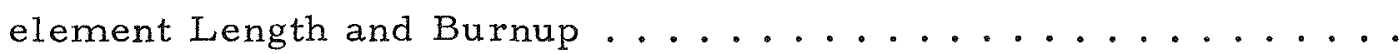

4. Effect of Irradiation on FTR Cladding Strain during $10^{\circ} \mathrm{F} / \mathrm{sec}$ and

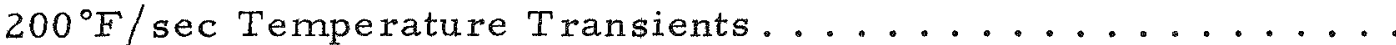

5. Range of Microstructures Developed in Type 316 Stainles steel as a Function of Temperature and Neutron Fluence ........

6. Effect of Thermomechanical Treatments on Room-temperature

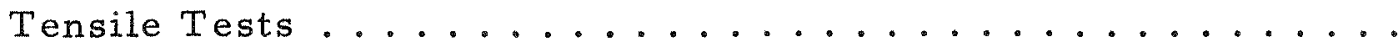

7. Effect of Thermomechanical Treatments on 550 and $650^{\circ} \mathrm{C}$

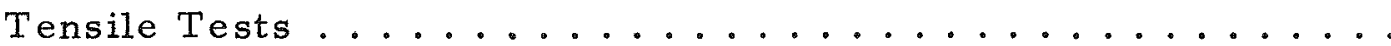

8. Cross-sectional Views of Type 316 Stainless Steel, 15-mil-wall,

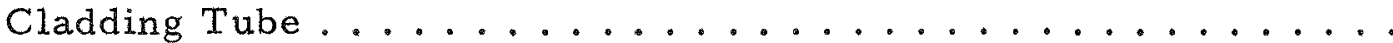

9. Plot of True and Engineering Stress-Strain Behavior of $20 \%$ Coldworked Type 316 Stainless Steel Extruded Duct ...........

10. Plot of True and Engineering Stress-Strain Behavior of $50 \%$ Coldworked Type 316 Stainless Steel Extruded Duct ..........

11. Effect of Grain-boundary Penetration by Cesium Oxides on the Biaxial Stress-rupture Behavior of Type 316 Stainless Steel at $704^{\circ} \mathrm{C} \ldots \ldots \ldots \ldots \ldots \ldots \ldots$

12. Predicted Cladding Wastage in a 36-in.-1ong Fuel Element That Has Operated at $12 \mathrm{~kW} / \mathrm{ft}$ for 320 Full-power Days to a Burnup of $80,000 \mathrm{MWd} / \mathrm{MTM} \ldots \ldots \ldots \ldots \ldots$ 


\section{LIST OF TABLES}

No.

Title

Page

I. Results of Transient Heating Tube-burst Tests on Reference

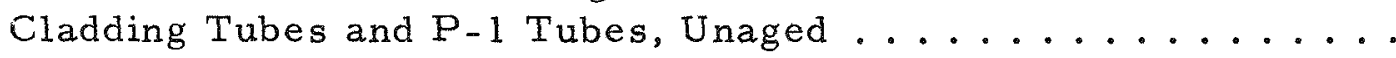

II. Results of Transient Heating Tube-burst Tests on P-I after Aging, 50\% Cold Worked before and after Aging, and Thinned

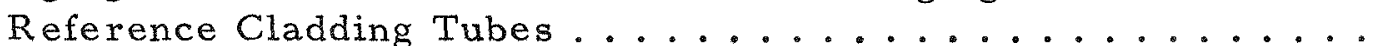

III. Summary of Transient Heating Tube-burst Results from Table I. . 20

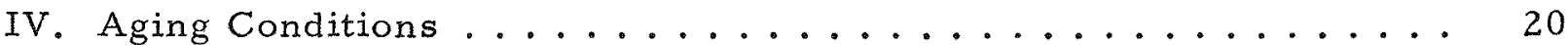

V. Strength and Ductility of Cold-worked Type 316 Stainless Steel Duct Material at Room Temperature ............... 
- 


\title{
FUEL-ASSEMBLY MATERIALS SIMULATION PROGRAM: STATUS REPORT
}

by

J. T. A. Roberts, J. J. Weins,

C. A. Youngdahl, F. L. Yaggee,

P. S. Maiya, and J. E. Spruiell

\begin{abstract}
This report presents the results and preliminary recommendations from the first year of effort to simulate the effects of irradiation in fuel-assembly materials. The objective was to develop thermomechanical and thermochemical treatments of Type 316 stainless steel that will reduce metal ductility to the $\$ 1 \%$ strain level during heating ramps of $\sim 6-111^{\circ} \mathrm{C} / \mathrm{sec}$ $\left(10-200^{\circ} \mathrm{F} / \mathrm{sec}\right)$.

A $50 \%$ cold-worked, or $50 \%$ cold-worked and aged, Type 316 stainless steel cladding tube fails after $<1 \%$ stable strain at $2100-2300^{\circ} \mathrm{F}$, when subjected to a $200^{\circ} \mathrm{F} / \mathrm{sec}$ heating ramp, but undergoes some recovery at the lower heating rates. A uniformly nitrided cladding tube, on the other hand, maintains the $<1 \%$ strain embrittlement level under $10^{\circ} \mathrm{F} / \mathrm{sec}$ heating. It is therefore concluded that either thermomechanical or thermochemical treatment of Type 316 stainless steel can provide a basis for the simulation of cladding and duct materials, but the thermomechanical approach will be limited to either roomtemperature tests or accident simulations involving rapid thermal transients.

The study also included the effects of fission products and sodium on Type 316 stainless steel and the effects of irradiation on the oxide fuel. The former could be simulated effectively by a simple reduction in cladding-or duct-wall thickness. Cracking and restructuring of the fuel could be achieved by a short preirradiation before the accident experiment, but fissiongas buildup could not be simulated. It was therefore recommended that irradiated fuel be used in the experiment in which these effects might be important.
\end{abstract}




\section{INTRODUCTION}

An experimental program to study fuel-element failure and failure propagation under interrupted coolant flow conditions is being implemented. ${ }^{1}$ The Sodium Loop Safety Facility (SLSF) has been designed to perform tests with large fuel bundles in an environment prototypic of the Fast Flux Test Facility (FFTF). ${ }^{2}$ The thermal-hydraulic behavior of the loop approximates that of FFTF, and, during the experiment, the fission rates will be matched with those expected in FFTF. However, to complete the valid simulation of some accident conditions, it is necessary to account for the effect of irradiation on the behavior and properties of fuel, cladding, and subassembly duct materials during the fuel-burnup cycle. The status of our study of approaches that might be used to achieve simulated reactor materials for the SLSF test program is presented. For reasons that are described, the near-term emphasis was on the simulation of the mechanical response of highly irradiated cladding and duct materials. Methods to achieve ductilities of $\leqslant 1 \%$ at high temperatures are discussed.

\section{BACKGROUND}

Any consideration of techniques for simulation of the properties of ir radiated fuel, cladding, and duct materials must be prompted by irradiation costs, availability of irradiated materials, and experimental requirements of the SLSF Program. The need to study the behavior of full-length $(36-i n$. assemblies subjected to either local-or whole-subassembly loss-of-coolant conditions dictates the use of unirradiated materials, because no fast-flux facility can irradiate 36-in. assemblies. When these full-length unirradiated assemblies are tested, it will be desirable to simulate the significant irradiated materials and behavior that affect the accident consequences. In some cases, local failure phenomena can be studied by using actual irradiated fuel elements, since shorter (13-in.) EBR-II elements may be available. However, the costs and irradiation times for these fuel elements are great (e.g., fabrication and irradiation will take $3 \frac{1}{2}-4$ yr to attain $8 \%$ burnup), and this may result in program delays. Therefore, simulation of irradiation effects is an attractive proposition for most safety-testing needs, if no additional problems are introduced.

Basically, two accident types--local subassembly malfunction and whole-subassembly loss-of-flow (LOF) accident--are studied in the SLSF, and the simulation requirements are thought to be different for each. First, the local subassembly malfunction may lead to failure propagation among fuel elements or between subassemblies. In this case, the fuel-failure threshold for local asymmetric thermal perturbations appears to be a key issue in the initiation of the accident sequence. The response of fuel and duct material to thermal-mechanical loads is a further consideration. (The SLSF P $-1,-4,-8$, -9 , and -10 tests are examples of such accidents. The $P$-designation is given to experiments planned for the SLSF.) 
Second, the whole-subassembly LOF accident leads to rapid coolant expulsion, cladding and fuel melting, and subsequent dispersal of both fuel and cladding. Thus, in the LOF case, the fuel-failure threshold and fissiongas release are important because the coolant flow and voiding are affected. Subsequent fuel and cladding dispersal during this more rapid symmetric thermal transient is also important. (The SLSF P-2 and -5 tests are examples of the LOF type of accident.)

For each type of accident, it is necessary to define the fuel-burnup condition that (1) makes the fuel element most sensitive to failure, and (2) exerts the greatest influence upon the ultimate accident consequences. These accident types are discussed in greater detail, and "worst-case" fuelburnup conditions are suggested.

\section{A. Local-subassembly Malfunctions}

For local-subassembly malfunctions, the "worst condition" may well depend on the time scale of the accident. In local blockages that develop over hours, the fission gas in the fuel might be unimportant relative to the plenumgas inventory, inasmuch as fuel swelling caused by local overheating in the outer fuel zones could be accommodated in the space provided by porosity, pellet dishes, or central void. Thus, one might suggest that a "worst case" would be an end-of-life (EOL) high-power element. Failure would result from the increased plenum-gas pressure leading to an increase in hoop stress on the embrittled cladding. Thus, in a cladding-overheating situation, the element would behave as an internally pressurized tube.

On the other hand, rapid overheating caused by local blockages that form in seconds (or less) would produce strain caused by increased swelling in the outer fuel zones due to fission-gas bubble precipitation, coalescence, and growth, and/or by dynamic gas-pressure-induced separation of grains at the grain boundaries. The resultant volume increase of the fuel would strain the cladding and add to the plenum-gas-pressure effects. [T. Weber (Hanford Engineering Development Laboratory) observed a type of explosive fuel separation in his heating experiments. However, since fuel failure occurred close to the onset of melting, it was not clear whether the explosive action was due to gas release on melting or fuel cracking.] The cladding strain caused by this type of mechanism would, of course, depend on the time scale of the event and the state of the cladding. However, the major considerations would be the amount of fission gas in the fuel, the condition of the fuel, and its response to temperature. In this situation, the "worst case" might be a middle-of-life (MOL) or EOL low-to-medium-power fuel element in which the fuel initially strains the cladding; i.e., the fuel-cladding gap is closed, and most of the fission gas is retained.

To summarize the local-subassembly malfunctions, at least two "worst fuel-element conditions" can be defined: (1) an EOL high-power element and (2) a MOL or an EOL low-to-medium-power element, i.e., a gassy fuel condition. 
B. Whole-subassembly LOF Accidents

For a whole-subassembly LOF accident, probably all burnup levels (including all cladding conditions) are of interest. Indeed, the concept of a "worst condition" may not be applicable to this type of hypothetical accident. An analysis of the LOF accident is quite detailed, and the trend is toward the development of a completely mechanistic description.

\section{ASSESSMENT OF SLSF EXPERIMENTAL REQUIREMENTS}

Inasmuch as EOL fuel-element failure appears to be limited only by the extent of cladding embrittlement and the internal gas pressure, this element type provides fewer simulation requirements. Therefore, SLSF tests that require full-length subassemblies, such as P-1 through -6 , should use EOL simulations or beginning-of-life (BOL) conditions. These tests are principally the LOF type, and the effects of fuel-failure threshold, sodium boiling, and fission-gas voiding will be studied. The fuel should be in the prototypic structural condition (i.e., central hole and cracks), since it will provide impedance to gas release from the plenum after cladding failure. Thus, the simulation requirements for an EOL high-power element will be (1) a high plenum gas pressure that can be obtained by prepressurizing the element to a specified pressure (Fig. 1), ${ }^{3}$ (2) fuel-cladding-gap closure and complete fuel restructuring characteristic of high-power EOL elements, and (3) the cladding conditions. The state of embrittlement and the mode of failure of the cladding are important, as is shown in Fig. 2. 4 The total strain to failure can be reduced by as much as an order of magnitude, and the cladding can be corroded to half its thickness by fission product and sodium attack. All these effects must be simulated to reproduce the expected mechanical response.

If lower burnup levels are of equal importance for LOF analyses, then it is recommended that the SLSF P-5 test, for example, use fuel irradiated to

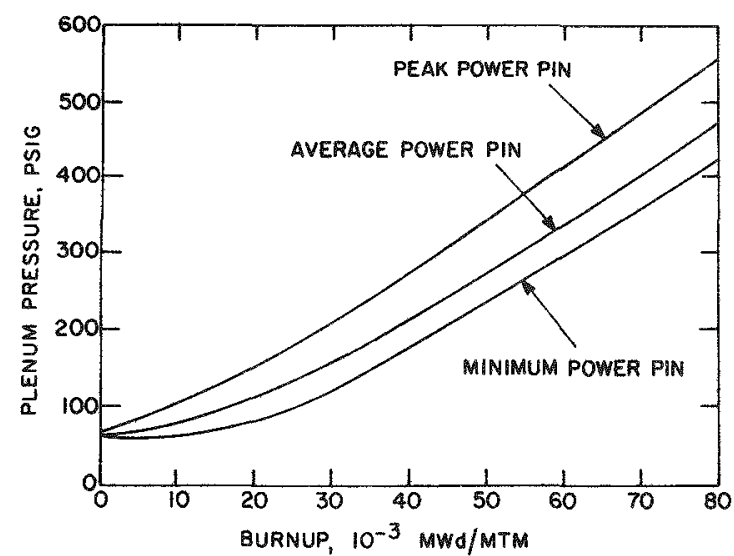

Fig. 1. Predicted Plenum Pressure for FTR Fuel Elements. Neg. No. MSD-60315. a low burnup level in the Experimental Test Reactor (ETR), i.e., to at least 20,000 MWd/MTM to maximize fissiongas retention (Fig. 3), ${ }^{3}$ with cladding that has the appropriate simulated properties to match the specified fuel conditions. This approach would provide the most prototypic test for an LOF accident, since the fuel would have an appreciable quantity of retained fission gas in the microstructure.

In addition, the SLSF P-4 through -6 tests call for the duct material to be in a correct irradiated structural condition, since its response to the thermal and 
mechanical impact of molten material will determine whether subassemblyto-subassembly failure propagation is possible under these conditions. Duct materials can be preirradiated for use in these tests, but, if a simulation approach were used, it could result in a saving of time and money. A 3- to 4-yr irradiation would be necessary in EBR-II to generate the required EOL type of fluence. The problem is not quite the same as simulating cladding, since the irradiation temperature is lower and no fission-product attack is present. The major requirement for simulation in duct materials will be to reproduce impact strength and ductility during a thermal and mechanical transient.

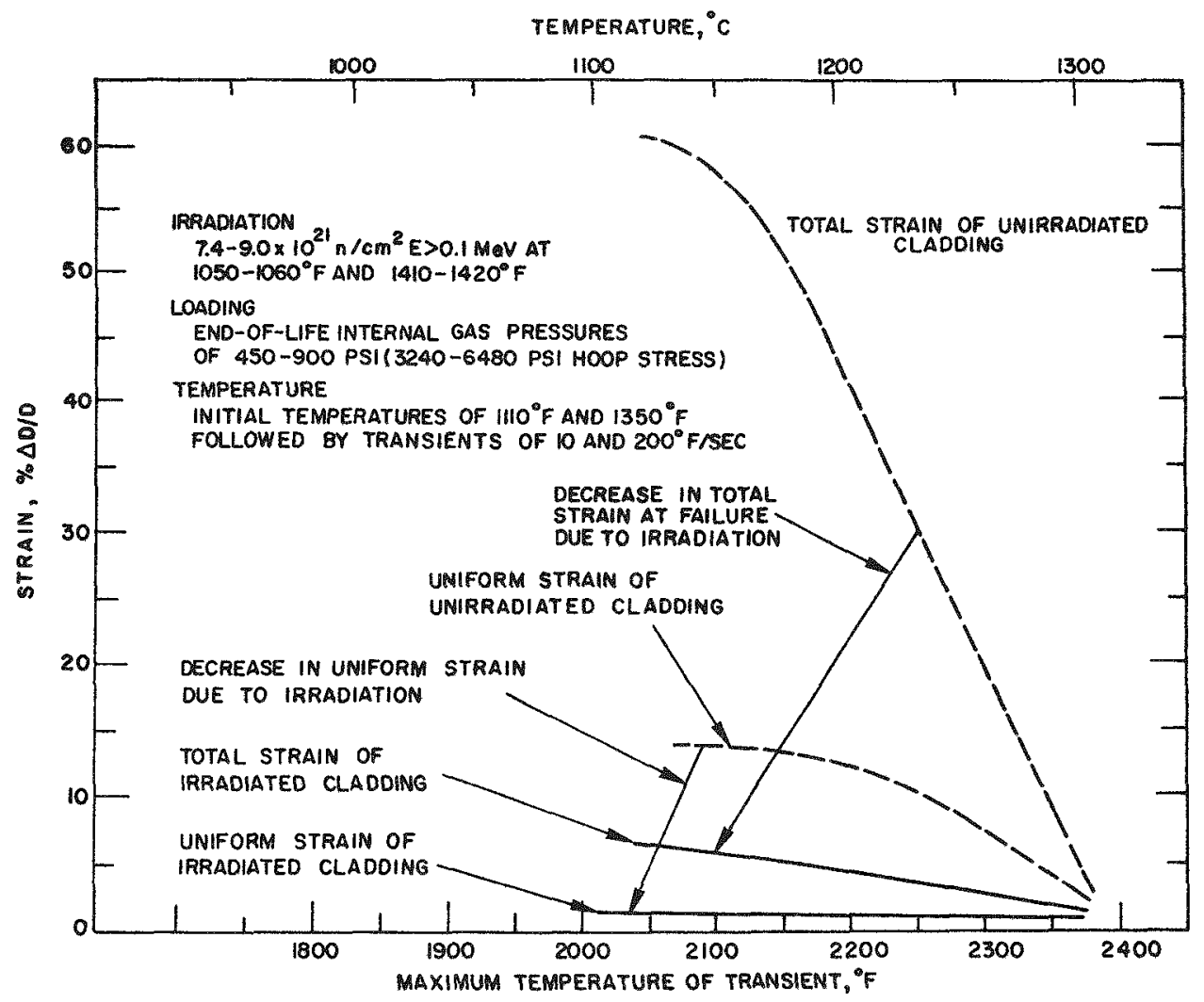

Fig. 2. Effect of Irradiation on the Strain of 20\% Cold-worked Type 316 Stainless Steel Fuel Cladding under EOL Loading Conditions during Temperature Transients Simulating LOF Accidents. Neg. No. MSD-60316.

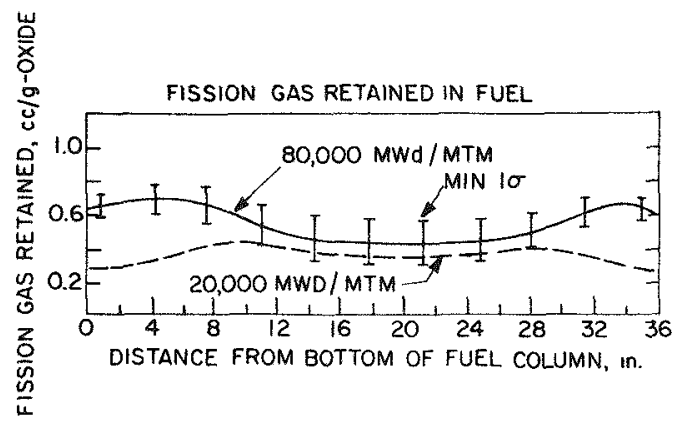

(a)

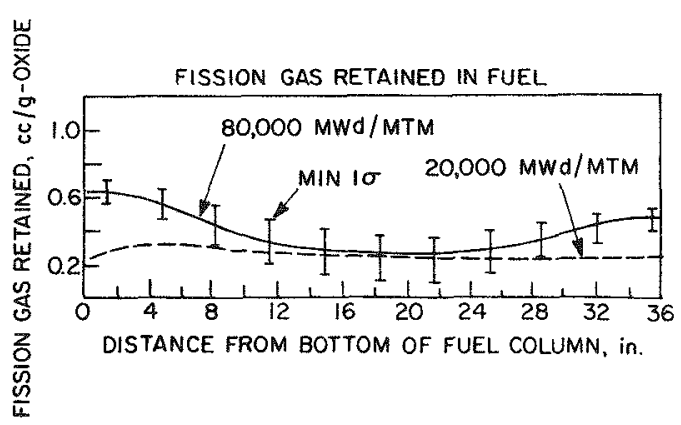

(b)

Fig. 3. Predicted Fission Gas Retained in Fuel as a Function of Fuel-element Length and Burnup. (a) Minimum power pin. (b) Average power pin. Neg. No. MSD-59836. 
In later experiments (SLSF P-7 and others) in which local phenomena (e.g., internal blockage, inlet blockage, and gas release) are studied, the fuel condition, particularly fission gas in the fuel, is quite important. Irradiated fuel is essential here because no obvious ways are available to simulate the correct fission-gas bubble morphology. However, if some method could be devised to minimize EBR-II irradiation time, costs could be reduced and experiments could be completed on schedule.

If it is assumed that the "worst case," from the standpoint of local failure phenomena, is EOL because internal gas pressures are high, fuel is badly cracked, and cladding is thin and weak, a lead time of $3 \frac{1}{2}-4$ yr would be necessary to fabricate and irradiate fuel elements to $\sim 8$ at. $\%$ burnup. However, simulation could save time (and perhaps money) by reducing the irradiation time by a factor of four. A procedure that could be adopted to reduce irradiation time and cost would be the following. Fission-gas retention in fuel remains relatively constant from 20,000 to 80,000 MWd/MTM (e.g., Fig. 3), but fission-gas release increases somewhat linearly with burnup (Fig. 1) and cladding embrittlement increases with burnup (Fig. 2). It may be possible to introduce extra plenum fission gas to achieve the correct pressure after irradiation. Therefore, if one could start irradiation with a partially embrittled, sensitized cladding to account for the extra fluence and corrosion attack, then the actual irradiation time could be reduced by a factor of four and still achieve "prototypic" EOL fuel conditions. Again, the key to the problem is the simulation of cladding mechanical properties.

In summary, the simulation effort will concentrate on reproducing the mechanical behavior of irradiated Type $31620 \%$ cold-worked stainless steel. Different conditions exist for cladding and duct materials, but the same principles must hold. We will rely on reduced irradiation times (e.g., short, $\leq 5$ days) to establish the cracked fuel structure and restructuring necessary for the full-length elements.

\section{CLADDING-DUCT M.ATERIALS SIMULATION}

A. Objectives and Scope

In the SLSF experiments, both cladding and duct materials are expected to be subjected to thermal transients of $\gtrsim 111^{\circ} \mathrm{C}\left(200^{\circ} \mathrm{F}\right) / \mathrm{sec}$ (under different mechanical-loading conditions), starting from prototypic FTR operating temperatures $\left(\sim 450-650^{\circ} \mathrm{C}\right.$ cladding-midwall and $\sim 420-550^{\circ} \mathrm{C}$ duct temperature). The objective of this materials-simulation effort is to reproduce, in unirradiated Type 316 stainless steel or other acceptable steels, the correct mechanical response of such systems after EOL fluences of $\gtrsim 1 \times 10^{23} \mathrm{n} / \mathrm{cm}$. Since no $20 \%$ cold-worked Type 316 stainless steel has received this fluence level to date, predictions of expected cladding behavior must be made from out-of-reactor tube-burst data at much lower fluences $\left(2.75 \times 10^{22} \mathrm{n} / \mathrm{cm}^{2}\right) .^{5}$ At EOL fissiongas pressures, Fish et $a 1 .{ }^{5}$ observed a stable strain of $\sim 0.5 \%$ and a failure 
temperature of $\sim 1170^{\circ} \mathrm{C}\left(2138^{\circ} \mathrm{F}\right)$; the maximum stable strain was only $\sim 1 \%$. Thus, a large reduction in ductility is achieved in irradiated Type 316 cladding tested at high temperatures (Fig. 4).

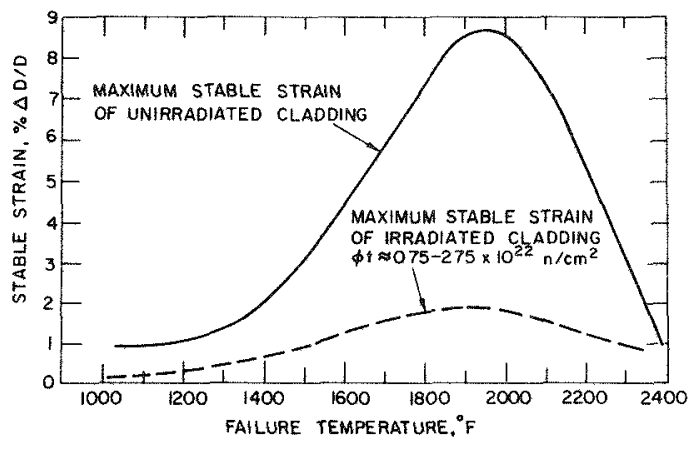

(a)

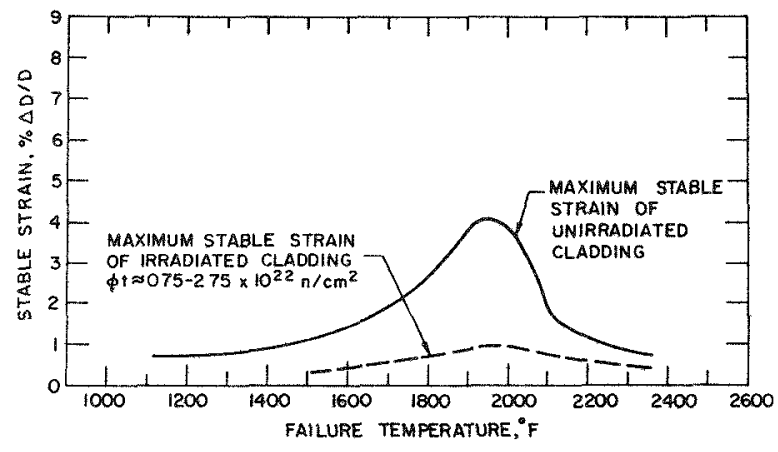

(b)

Fig. 4. Effect of Irradiation on FTR Cladding Strain during (a) $10^{\circ} \mathrm{F} / \mathrm{sec}$ and (b) $200^{\circ} \mathrm{F} / \mathrm{sec}$ Temperature Transients (20\% cold-worked Type 316 stainless steel). Neg. Nos, MSD-60317 and -60318 .

Some insight into the reason for this embrittlement can be obtained from the correlation developed by Holmes et al. ${ }^{6}$ for solution-annealed Type 316 stainless steel. Figure 5 is a graphical representation of microstructures developed as a result of neutron irradiation and temperature. Although domain boundaries are likely to be influenced by the presence of precold work, it is evident that ductility loss in Type 316 stainles steel is associated with matrix strengthening from dislocations and voids and is aggravated by the presence of helium at grain boundaries. Bloom and Stiegler's ${ }^{7}$ investigations

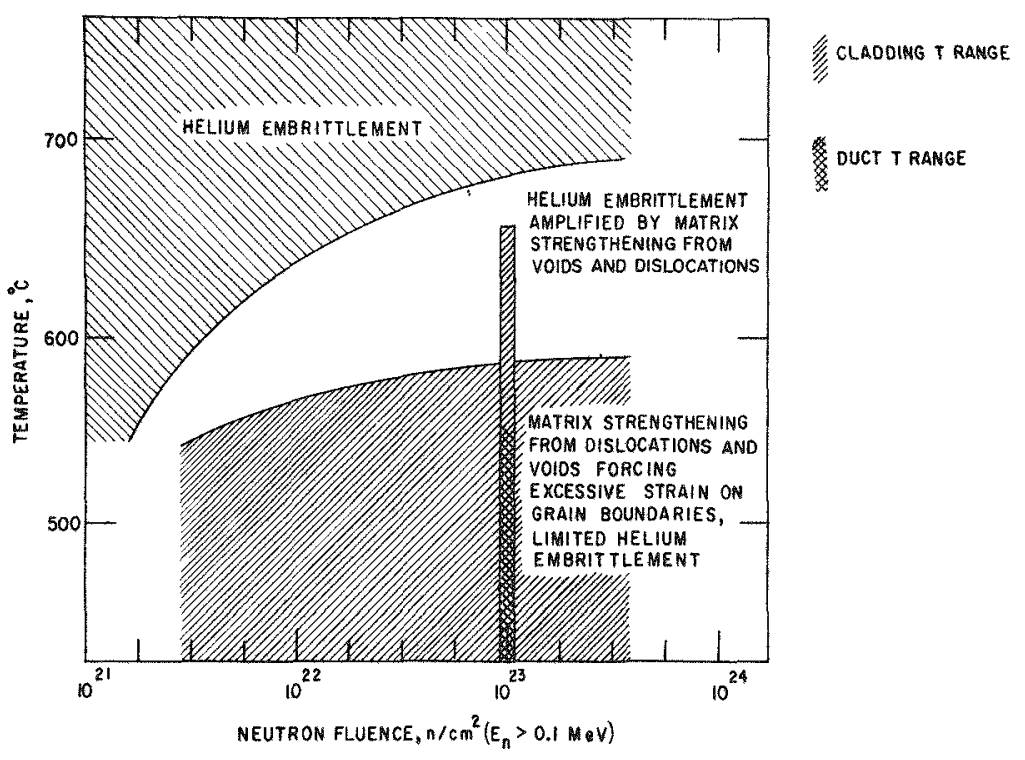

Fig. 5. Range of Microstructures Developed in Type 316 Stainless Steel as a Function of Temperature and Neutron Fluence. Neg. No. MSD-59835. 
on Type 316 stainless steel indicate that the large decrease in ductility results from enhanced intergranular fracture, which is promoted by the linking of cavities nucleated at helium bubbles.

Our preliminary research effort has attempted to achieve grain-matrix strengthening and $\mathrm{grain}$-boundary weakness, initially through thermomechanical treatments of Type 316 stainless steel. As a basis for this work, we used the results of Spruiell et al. ${ }^{8}$ who adopted this technique to establish microstructures in Type 316 stainless steel that contained various amounts of embrittling phases both in the matrix and at the grain boundaries. Also, we have initiated a study of the nitriding of Type 316 stainless steel.

Our simulation work will also take into account the influence of cladding corrosion (from the combined effects of sodium and fission products) on the high-temperature mechanical behavior of Type 316 stainless steel cladding. Therefore, experiments were undertaken to determine the effect(s) of chemical corrosion on creep-rupture strength and failure mode, and an effort was made to obtain the best available data on cladding wastage as a function of temperature and burnup.

\section{B. Experimental Procedure and Results}

\section{Thermomechanical Treatments of Type 316 Stainless Steel}

Both ambient and elevated-temperature tests were conducted on cold-worked and aged Type 316 stainless steel to establish the range of tensile properties that can be achieved by thermomechanical pretreatments. All samples were solution-treated at $1050^{\circ} \mathrm{C}\left(1922^{\circ} \mathrm{F}\right)$ before further treatment. Mechanical treatments were carried out by cold rolling. The reductions in

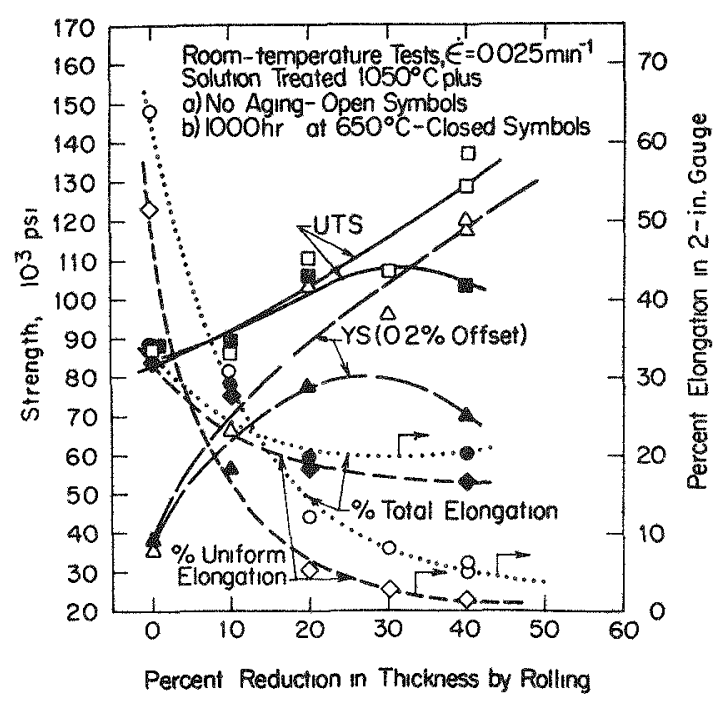

Fig. 6. Effect of Thermomechanical Treatments on Room-temperature Tensile Tests. Neg. No. MSD-60313. thickness were chosen so that the final thicknesses of the as-prepared sheet tensile samples were nominally 0.030 in. The gauge section of each sample was 0.250 in. wide by 2 in. long. During aging treatments, the samples were encapsulated in evacuated Inconel tubes.

The results of tests conducted at room temperature and a strain rate of $0.025 \mathrm{~min}^{-1}$ are shown in Fig. 6. This figure compares the tensile properties of as-cold-rolled samples with the properties of samples that have been cold-rolled and aged for $1000 \mathrm{hr}$ at $650^{\circ} \mathrm{C}\left(1202^{\circ} \mathrm{F}\right)$. This aging treatment results in the precipitation of $\mathrm{M}_{23} \mathrm{C}_{6}$ carbide, Laves phase, and, at the larger reductions, some sigma phase. ${ }^{8,9}$ In as-solution-treated samples 
( $0 \%$ reduction), the precipitates are concentrated mainly in or near the grain boundaries, which resulted in a decrease in the ductility with little change in yield and ultimate tensile strengths. Samples with reductions $>10 \%$ underwent an increase in ductility and a decrease in yield and ultimate tensile strengths when aged, in contrast to the unaged condition. In the $>10 \%$ reduced samples, the precipitation occurred in the deformation bands as well as in the grain boundaries and depleted the austenite matrix of solute. This effect, together with the recovery processes that occurred during the aging treatment, resulted in the observed property changes. Metallographic examination of the

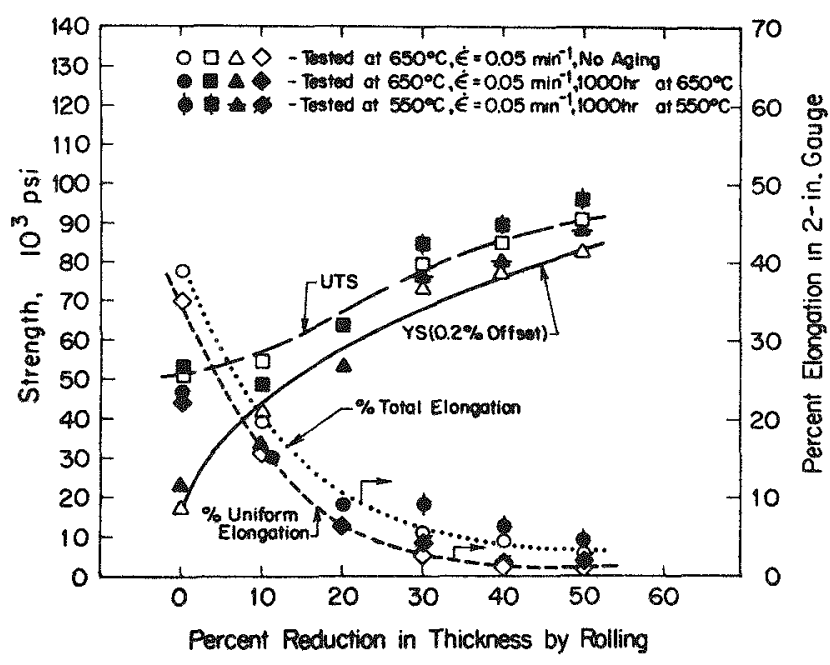

Fig. 7. Effect of Thermomechanical Treatments on 550 and $650^{\circ} \mathrm{C}$ Tensile Tests. Neg. No. MSD-60314. tensile-tested samples showed that, in agreement with the results of Spruiell et al. ${ }^{8}$ the sample reduced $40 \%$ had begun to recrystallize during the subsequent aging treatment.

Figure 7 presents the results of tests conducted at 650 and $550^{\circ} \mathrm{C}$ $\left(1202\right.$ and $1022^{\circ} \mathrm{F}$ ) and a strain rate of $0.05 \mathrm{~min}^{-1}$. Since low ductility at test temperatures is one prerequisite to successful simulation of the properties of irradiated materials, aging and testing were performed at $550^{\circ} \mathrm{C}$ rather than $650^{\circ} \mathrm{C}$ for samples reduced $30 \%$ or more. The mechanical properties shown in Fig. 7 are from samples that did not reveal any evidence of recrystallization in the posttest microstructures. The uniform elongations of $\sim 1.3 \%$ for samples, reduced 40 and $50 \%$ by cold work and aged $1000 \mathrm{hr}$ at $550^{\circ} \mathrm{C}$, indicate that a heavily cold-worked Type 316 stainless steel cladding (or duct) should retain low ductility during a simulation that does not require heating to temperatures above $550^{\circ} \mathrm{C}$ or excessively long holding times near $550^{\circ} \mathrm{C}$. According to the data of Spruiell et al. ${ }^{8}$ recrystallization should begin in a $50 \%$-reduced cold-rolled sample after $3000 \mathrm{hr}$. The effect of rapid heating on cold-work recovery rates is difficult to assess on the basis of these results. Tube-burst tests of the type described in Sec. IV.B. 3 below are necessary to characterize transient deformation behavior.

\section{Thermochemical Treatments of Type 316 Stainless Steel}

Only preliminary results were obtained from the nitriding and carburizing study. The objectives, as before, were to develop low ductility and to promote intergranular failure similar to that expected in highly irradiated Type 316 stainless steel.

The embrittling treatment consisted of equilibrating the claddingtube sample and the additive in a sealed quartz capsule at $1000^{\circ} \mathrm{C}$ for 6 days, 
followed by furnace cooling overnight. (The minimal conditions have not been established.) To produce carburized samples, the tube surfaces were coated with DAG (colloidal graphite in alcohol) and dried before vacuum encapsulation. To make nitrided samples, the capsule size was chosen to provide the desired quantity of nitrogen when the capsule was backfilled to 1 -atm (0-psig) nitrogen pressure before sealing. To date, we have aimed at converting all chromium in the tube to $\mathrm{Cr}_{23} \mathrm{C}_{6}$ or $\mathrm{Cr}_{2} \mathrm{~N}$. As discussed below, carburized samples possessed much smaller grain size than nitrided samples. In recent equilibrations, we substituted $20 \%$ of the additive as carbon (i.e., DAG was painted on the surface), and the equilibration was carried out in a nitrogen atmosphere to retain the small grain size in nitrided tubes.

Microstructures were examined from 1-in. -long cladding-tube specimens subjected to the treatments described above and were compared with either as-received material or with samples vacuum-annealed in quartz under the same temperature conditions (Fig. 8). The unheated and the carburized materials had $\sim 30$ grains across the wall, whereas the vacuum-treated materials had as few as four grains; the nitrided samples were of intermediate grain size. The 15-mil-wall thickness was not visibly affected by the treatments. Grain outlining and matrix precipitates were visible without etching the polished nitrided metal. The distribution of precipitates was quite uniform across the wall thickness in the carburized and nitrided samples, except for an extremely shallow surface effect. This effect might be eliminated by activity-control procedures or, for nitrided specimens, by more rapid cooling after equilibration. The appearance of more recently carburized tubes suggests that no surface effect will be seen when their microstructures are examined metallographically.

To date, only one mechanical test has been conducted, but the results are encouraging. The first nitrided tube produced displayed only $0.77 \%$ average $(0.81 \% \mathrm{max})$ stable strain at failure and a burst temperature of $1321^{\circ} \mathrm{C}$ $\left(2410^{\circ} \mathrm{F}\right)$ when tested at $\sim 6^{\circ} \mathrm{C} / \mathrm{sec}\left(10^{\circ} \mathrm{F} / \mathrm{sec}\right)$ in the transient tube-burst apparatus described in Sec. IV.B. 3 below. This level of embrittlement is comparable to the conditions expected in highly irradiated Type 316 stainless steel (Sec. IV.A) and appears to be more thermally stable than the heavily cold-worked structures reported in Sec. IV.B. 3.

\section{Transient Tube-burst Tests on Simulated Cladding}

Transient heating of internally pressurized cladding sections was used to characterize the high-temperature failure behavior of the simulant materials. The results reported here are on 20,38 , and $50 \%$ cold-worked Type 316 stainless steel cladding tubes. The $38 \%$ cold-worked material had been chosen for the SLSF P-1 test. For convenience, we report all tube-burst temperatures and heating rates in ${ }^{\circ} \mathrm{F}$ to facilitate comparison with the results of Fish et al. ${ }^{5}$ which constitute our primary reference for the present work. Aging temperatures are given in ${ }^{\circ} \mathrm{C}$. 


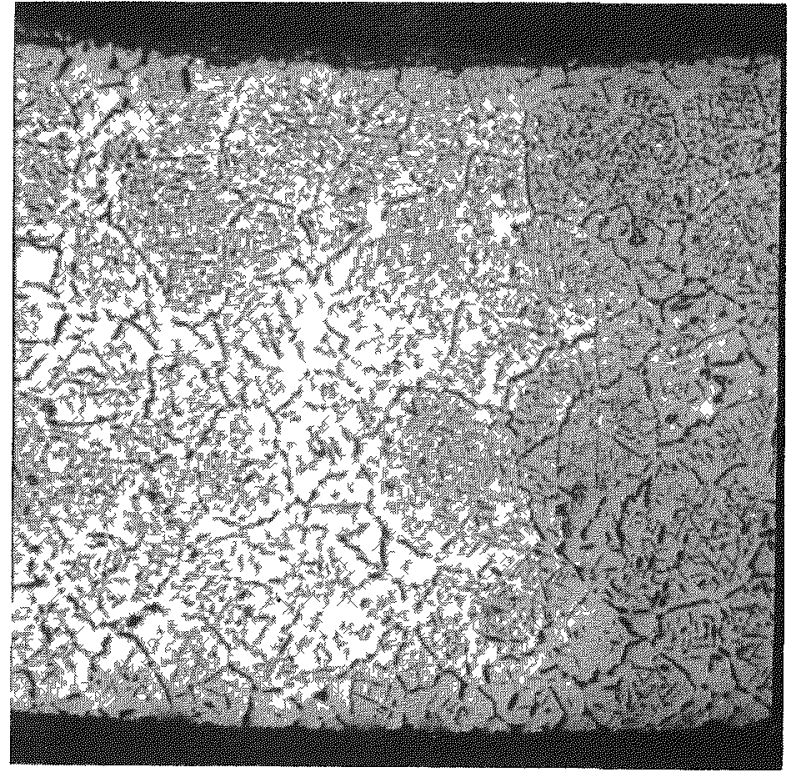

(a) Nitrided

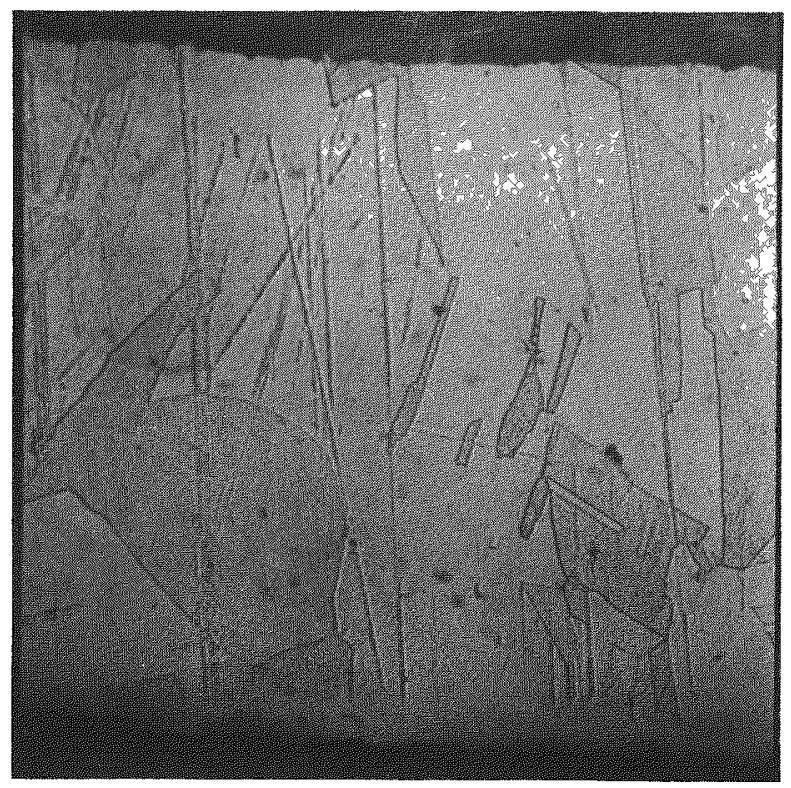

(c) Vacuum Treated in Quartz Capsule with Same Thermal Cycle as Nitrided-Carburized Samples

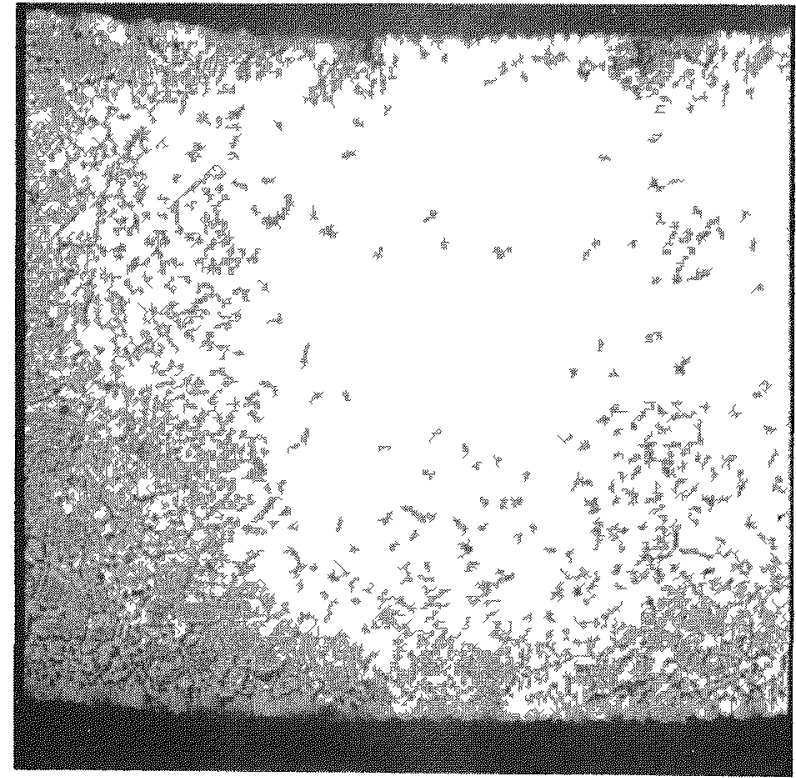

(b) Carburized

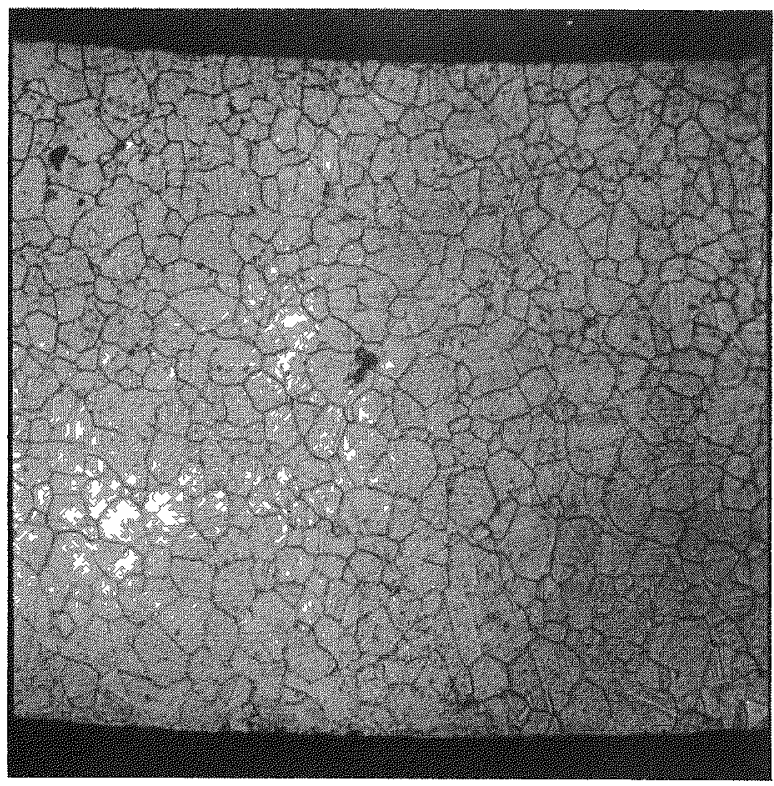

(d) As-received Tubing (Contained 20\% Cold Work)

Fig 8. Cross-sectional Views of Type 316 Stainless Steel 15-mil-wall Cladding Tube. Oxalic acid etchant. The entire wall thickness is shown in each view See text for treatment details Original Mag. 200X Neg. Nos. MSD-60122 and -60121.

A tube-burst apparatus capable of simulating transient in-reactor heating effects was constructed especially for this program. A major requirement was to record both the fallure temperature and the time 1nto the ramp when fallure occurred Failure strain and fallure mode can be observed in the posttest examination, since the heating was terminated at failure. 
The transient burst-test apparatus used a 6-V, 60-cycle power source to resistance-heat the test sections. A Variac controlled the sample current and thereby varied the temperature ramp. A temperature ramp as high as $\sim 167^{\circ} \mathrm{C}\left(300^{\circ} \mathrm{F}\right) / \mathrm{sec}$ can be obtained. One end of the test specimen was sealed with a Swagelok fitting; the other was connected through a Swagelok and check valve $(0.3 \mathrm{psi})$ to a pressure gauge and gas reservoir. The internal volume of the tube and fittings was reduced by inserting machined void slugs to minimize postburst damage to the burst site by flowing gas. An impervious alumina slug within the sample tube occupied $80 \%$ of the volume between the Swagelok fittings. The gas reservoir, with a volume more than 100 times the void volume of the specimen, was used to maintain a relatively constant pressure $(420 \mathrm{psia})$ in the sample during heating.

The samples were tested in a vacuum bell jar that had been flushed with argon and evacuated to $25 \mathrm{wm}$ before testing. In each case, the sample was held $1-2 \mathrm{~min}$ at $700^{\circ} \mathrm{F}$ before starting the ramp. The failure of the tube during the high heating ramps of $200^{\circ} \mathrm{F} / \mathrm{sec}$ was detected by a contact microphone placed inside the bell jar. For lower heating ramps, such as $10^{\circ} \mathrm{F} / \mathrm{sec}$, failure was detected by an abrupt increase in bell-jar pressure, as indicated by a vacuum gauge. The temperature of the tube during testing was recorded on a high-speed recorder, connected to a small-diameter (1-mil wire) thermocouple spark welded to the center of the cladding-tube specimen. Typically, the reported burst temperature is estimated to be within $25^{\circ} \mathrm{F}$ of the correct value at the point of thermocouple-sample contact. However, relatively cool local zones have been observed within the middle zone during the $200^{\circ} \mathrm{F} / \mathrm{sec}$ tests, and some strain and burst-temperature results may be affected by this phenomenon.

The overall length of the Type 316 stainless steel cladding-tube samples was 6 in., which did not change appreciably during a transient run. The central 4 in. was a zone of relatively uniform temperature, the middle 3 in. of which was considered the zone of interest. The dimensions of the tube samples were obtained every $0.5 \mathrm{in}$. of length before and after testing to provide data listed in Tables I and II. The initial outer diameters in the tables were nominally 0.230 in. (except for three machined tubes, which are discussed below).

When stable strain was large, and especially when substantial bulging occurred, the maintenance of sample pressure throughout the test was uncertain. Thus, the P-I samples were run with the check valve held open magnetically to permit gas flow in either direction through the valve. After March 25, 1974 (3/25 in Table I), the void-volume slugs were remachined to enlarge the gas-flow passages, and all samples of both tubing types were run with the check valve disabled (open to the plenum). Results with the modified apparatus tended to confirm the previous results. The principal effects of the larger flow passages were to produce a complete separation of burst-site material from the tube during a macrorupture and to sever the tube at the burst site. 
TABLE I Results of Transient Heating Tube burst Tests on Reference Cladding Tubes $20 \%$ cold-worked 15 mi wall $)$ and $P 1$ Tubes $(38 \%$ cold worked $10 \mathrm{mil}$ wall $)$ Unaged

\begin{tabular}{|c|c|c|c|c|c|c|}
\hline $\begin{array}{l}\text { Sample } \\
\text { Date }\end{array}$ & $\begin{array}{l}\text { Nomina! } \\
\text { Ramp Rate } \\
\text { of } / \mathrm{sec}\end{array}$ & $\begin{array}{c}\text { Average } D / D_{0} \\
\text { Stable }\end{array}$ & $\begin{array}{c}\text { Maximum } D / D_{0} \\
\text { Stable } e^{b}\end{array}$ & $\mathrm{Dmax}_{\text {max }} \mathrm{C}$ & $\begin{array}{l}\text { Burst } \\
\text { Moded }\end{array}$ & $\begin{array}{c}\text { Burst } \\
\text { Temperature } \\
\text { of }\end{array}$ \\
\hline \multicolumn{7}{|c|}{$20 \%$ Cold worked $15 \mathrm{mil}$ Wall } \\
\hline $2 / 15$ & 130 & 1059 & 1081 & 069 & 1 & $2360^{f}$ \\
\hline $2 / 20$ & 130 & 1008 & 1012 & 037 & 1 & $2380^{i}$ \\
\hline $3 / 13$ & 10 & $\sim 12$ & 12 & 030 & 2 & $2360^{f}$ \\
\hline $3 / 15$ & 200 & 1010 & 1014 & 043 & 1 & 2270 \\
\hline $3 / 18$ & 10 & 1137 & 1180 & 032 & 2 & $2370^{f}$ \\
\hline $4 / 1$ & 200 & 1009 & 1010 & 023 & None & $\sim 2000$ \\
\hline $4 / 3$ & 10 & 1217 & 1304 & 035 & 2 & $2340^{f}$ \\
\hline $4 / 5$ & 200 & 1013 & 1019 & 046 & 1 & 2750 \\
\hline $4 / 9(1)$ & 200 & 1011 & 1026 & 050 & 1 & 2270 \\
\hline $4 / 9(2)$ & 200 & 1011 & 1015 & 050 & 1 & \\
\hline $4 / 10(1)$ & 200 & 1009 & 1014 & 045 & 1 & 2070 \\
\hline $4 / 10+2)$ & 200 & 1009 & 1012 & 048 & 1 & 2300 \\
\hline \multicolumn{7}{|c|}{$38 \%$ Cold worked $10 \mathrm{mil} \mathrm{Wall}$} \\
\hline $12 / 18$ & 130 & 1036 & 1085 & 039 & 1 & $>2000$ \\
\hline $3 / 21$ & 10 & 1104 & 1111 & 035 & 3 & $\sim 2390^{f}$ \\
\hline $3 / 23$ & 200 & 1089 & 1180 & 031 & 2 & $\sim 2250^{f}$ \\
\hline $3 / 24$ & 200 & 1075 & 1113 & 082 & $i$ & \\
\hline $3 / 25$ & 200 & 1097 & 1140 & 042 & 1 & $2180^{f}$ \\
\hline $4 / 11(1)$ & 200 & 1075 & 1157 & 081 & 1 & $2250^{f}$ \\
\hline $4 / 1112)$ & 10 & 1146 & 1170 & 038 & 3 & 2090 \\
\hline $4 / 12$ & 200 & 1144 & 1232 & 075 & 1 & 2130 \\
\hline
\end{tabular}

a Sample pressure was constant at $420 \mathrm{psi}$ and the temperature was ramped at indicated rate after a 1 min hold at $700^{\circ} \mathrm{F}$

bFrom values obtained at 05 in intervals within the middle 3 in regton of the sample The values at the burst site or in severely stretch marked areas were omitted The ratio $0 / 00$ is the final outside diameter divided by the initial outside diameter clincludes any opened material at burst ste

d macrorupture 2 long buige small longitudinal crack and 3 localized bulge and crack outside of central zone eAn exceptionally low value ray imply loss of intimate thermocouple to sample contact

fposttest inspection showed thermocouple had not separated from sample during burst i e was still firmly attached to the sample

TABLE || Results of Transıent Heating Tube-burst Tests on P-1 after Aging $50 \%$ Cold Worked before and after Aging and Thinned Reference Cladding Tubes ${ }^{a}$

\begin{tabular}{|c|c|c|c|c|c|c|}
\hline $\begin{array}{l}\text { Sample } \\
\text { Date }\end{array}$ & $\begin{array}{l}\text { Nominal } \\
\text { Ramp Rate } \\
\text { of/sec }\end{array}$ & $\begin{array}{c}\text { Average } D / D_{0} \\
\text { Stableb }\end{array}$ & $\underset{\text { Stable }^{b}}{\text { Maximum }}{ }^{b / D_{0}}$ & $\mathrm{D}_{\max } \mathrm{C}$ & $\begin{array}{l}\text { Burst } \\
\text { Moded }\end{array}$ & $\begin{array}{c}\text { Burst } \\
\text { Temperature } \\
\text { of }\end{array}$ \\
\hline \multicolumn{7}{|c|}{$38 \%$ Cold-worked 10-mil Wall Aged } \\
\hline $\begin{array}{l}4 / 24 \\
4 / 25(1) \\
4 / 25(2) \\
4 / 26(1) \\
4 / 26(2) \\
4 / 30(2) \\
5 / 1 \\
5 / 2\end{array}$ & $\begin{array}{l}10 \\
10 \\
10 \\
10 \\
200 \\
200 \\
200 \\
200\end{array}$ & $\begin{array}{ll}1 & 059 \\
1 & 160 \\
1 & 138 \\
1 & 279 \\
1 & 040 \\
1 & 091 \\
1 & 026 \\
1 & 062\end{array}$ & $\begin{array}{l}1063 \\
1184 \\
1194 \\
1339 \\
1058 \\
1172 \\
1046 \\
11110\end{array}$ & $\begin{array}{l}025 \\
050 \\
038 \\
063 \\
069 \\
055 \\
075 \\
073\end{array}$ & $\begin{array}{c}2 \\
21 \\
3 \\
3 \\
1 \\
1 \\
1 \\
1\end{array}$ & $\begin{array}{l}2090 \\
2170 \\
2150^{9} \\
2210^{9} \\
2020 \\
2250^{9} \\
1870 \\
2350\end{array}$ \\
\hline \multicolumn{7}{|c|}{$50 \%$ Cold worked 15 mul Walt } \\
\hline $\begin{array}{l}5 / 8(1) \\
5 / 8(2)\end{array}$ & $\begin{array}{r}10 \\
200\end{array}$ & $\begin{array}{l}1164 \\
1008\end{array}$ & $\begin{array}{l}1200 \\
1012\end{array}$ & $\begin{array}{l}033 \\
050\end{array}$ & $\begin{array}{l}2 \\
1\end{array}$ & $\begin{array}{l}2300^{9} \\
2260\end{array}$ \\
\hline \multicolumn{7}{|c|}{$50 \%$ Cold worked $15-\mathrm{ml}$ wall Aged ${ }^{f}$} \\
\hline $\begin{array}{l}5 / 3 \\
5 / 7\end{array}$ & $\begin{array}{r}200 \\
10\end{array}$ & $\begin{array}{l}1006 \\
1063\end{array}$ & $\begin{array}{l}1009 \\
1109\end{array}$ & $\begin{array}{l}040 \\
033\end{array}$ & $\begin{array}{l}1 \\
3\end{array}$ & $\begin{array}{l}2080^{9} \\
2340^{9}\end{array}$ \\
\hline \multicolumn{7}{|c|}{$20 \%$ Cold worked Reference Cladding Machined to $10 \mathrm{mil}$ Wall } \\
\hline $\begin{array}{l}4 / 29(1) \\
4 / 29(2) \\
4 / 30(1)\end{array}$ & $\begin{array}{l}200 \\
200 \\
200\end{array}$ & $\begin{array}{l}1071 \\
1037 \\
1058\end{array}$ & $\begin{array}{l}1148 \\
1050 \\
1117\end{array}$ & $\begin{array}{l}071 \\
071 \\
077\end{array}$ & $\begin{array}{l}1 \\
1 \\
1\end{array}$ & $\begin{array}{l}2370 \\
2230 \\
2280\end{array}$ \\
\hline
\end{tabular}

a Sample pressure was constant at $420 \mathrm{psi}$ and the temperature was ramped at indicated rate after a $1 \mathrm{~min}$ hold at $700^{\circ} \mathrm{F}$

bfrom values obtained at 05 in intervals within the middle 3 in region of the sample the values at the burst site or in severely stretch-marked areas were omitted The ratio $\mathrm{D} / \mathrm{D}_{0}$ is the final outside diameter divided by the intial outside diameter cincludes any opened materiat at burst site

d) macrorupture 2 long bulge small longitudinal crack 3 localized bulge and crack outside of central zone and $3^{*}$ same within central zone

eAn exceptionally low value may imply loss of intimate thermocouple-to-sample contact

S See aging conditions Table IV

gposttest inspection showed thermocouple had not separated from sample during burst i e was still firmly attached to sample 
After exploratory runs with the apparatus, the results presented in Tables I and II were obtained. (Table III summarizes the results listed in Table I.) The 20\% cold-worked, 15-mil-wall cladding tube was considered the reference material. For this $20 \%$ cold-worked material, the slow ramps yielded greater values of stable strain and smaller openings at the burst sites than the rapid heating rates. The effect of heating rate was less consistent for P-1 (38\% cold-worked, 10-mil-wall) tubing, and the P-1 stable strain at high ramp rates was greater than that of the reference cladding tube.

TABLE III. Summary of Transient Heating Tube-burst Results from Table I

\begin{tabular}{|c|c|c|c|c|}
\hline \multirow{2}{*}{$\begin{array}{l}\text { Heating } \\
\text { Rate, } \\
{ }^{\circ} \mathrm{F} / \mathrm{sec}\end{array}$} & \multirow[b]{2}{*}{ Failure Mode } & \multirow{2}{*}{$\begin{array}{c}\text { Failure } \\
\text { Temperature, } \\
{ }^{\circ} \mathrm{F}\end{array}$} & \multicolumn{2}{|c|}{ Stable Strains ${ }^{a}$} \\
\hline & & & Average & Maximum \\
\hline \multicolumn{5}{|c|}{ 20\% Cold-worked, 15 -mil-wall Tubing } \\
\hline 200 & Invariably macrorupture & $2070-2300$ & $\sim 1$ & $1-2.6$ \\
\hline 130 & Invariably macrorupture & $2360-2380$ & $1-6$ & $1-8$ \\
\hline 10 & $\begin{array}{l}\text { Invariably long bulge with } \\
\text { small longitudinal crack }\end{array}$ & $2340-2370$ & $13-20$ & $18-30$ \\
\hline \multicolumn{5}{|c|}{$38 \%$ Cold-worked, $10-$ mil-wall Tubing $(\mathrm{P}-1)$} \\
\hline 200 & Generally macrorupture & $2130-2250$ & $7-15$ & $11-23$ \\
\hline 130 & Macrorupture & $>2000$ & $3-4$ & 8.5 \\
\hline 10 & $\begin{array}{l}\text { Crack on bulge outside of } \\
\text { middle zone }\end{array}$ & $\begin{array}{c}2090 ; 2390 \\
(\text { center })\end{array}$ & $10-15$ & $11-17$ \\
\hline
\end{tabular}

a Stable strains were measured within the middle 3 in. of the sample. The values were obtained from $\left(\mathrm{D} / \mathrm{D}_{0}-1\right) 100$.

The results of $10^{\circ} \mathrm{F} / \mathrm{sec}$ runs on several $\mathrm{P}-1$ samples were anomalous - the failures occurred as cracks on localized bulges situated outside the middle 3-in. zone of the samples. On sample 3/21, two bulges occurred 2 in. equidistant from the center of the tube. One of these sites [sample 4/25(1)] was monitored with an auxiliary thermocouple, and the sample temperature was found to be $39^{\circ} \mathrm{F}$ below the center temperature at the moment of burst. The burst-site anomaly cannot be explained at present.

Aging treatments at anticipated SLSF holding temperatures were applied to tubing containing 38 and $50 \%$ cold work, as described in Table IV. The aging was done in Vycor vacuum capsules containing tantalum getter strips. Each capsule was surrounded by a heavy-wall nickel sheath to ensure temperature uniformity during heat treatment and cooling.

TABLE IV. Aging Conditions

\begin{tabular}{lcc|ccc}
\hline $\begin{array}{l}\text { Sample } \\
\text { Date }\end{array}$ & $\begin{array}{c}\text { Time, } \\
\text { days }\end{array}$ & $\begin{array}{c}\text { Temperature, } \\
{ }^{\circ} \mathrm{C}\end{array}$ & $\begin{array}{c}\text { Sample } \\
\text { Date }\end{array}$ & $\begin{array}{c}\text { Time, } \\
\text { days }\end{array}$ & $\begin{array}{c}\text { Temperature, } \\
{ }^{\circ} \mathrm{C}\end{array}$ \\
\hline $4 / 24$ & 21 & 441 & $4 / 30(2)$ & 21 & $497^{\mathrm{a}}$ \\
$4 / 25(1)$ & 5 & 335 & $5 / 1$ & 21 & 611 \\
$4 / 25(2)$ & 21 & 335 & $5 / 2$ & 5 & 655 \\
$4 / 26(1)$ & 5 & 400 & $5 / 3$ & 5 & 650 \\
$4 / 26(2)$ & 5 & 497 & $5 / 7$ & 5 & 650 \\
\hline
\end{tabular}

ancluded an overshoot period of $<3$ days at $565^{\circ} \mathrm{C}$. 
As anticipated, aging reduced the average stable strain at failure. The effect tended to increase with an increase in aging time and temperature, as shown in Table II. However, P-l tubing that was aged under these conditions did not exhibit the low $\left(0.5-1 \%\right.$ at $\left.200^{\circ} \mathrm{F} / \mathrm{sec}\right)$ strain values desired.

The results with 50\% cold-worked, 15-mil-wall tubing (Table II) contrasted markedly with those of P-1. The behavior of the $50 \%$ cold-worked material was similar to that originally expected from the $P-1$ material. At $200^{\circ} \mathrm{F} / \mathrm{sec}$, the average stable strain at failure was $0.8 \%$, and, with aging, the strain was reduced to $0.6 \%$. At $10^{\circ} \mathrm{F} / \mathrm{sec}$, the aged material exhibited $\sim 6 \%$ stable strain, nearly 10 times as great as that during our first test on nitrided material. Obviously, cold work is not stable at the low heating rates. Burst temperatures were within the desired range.

The results shown in Table I were compared with those of similar tests conducted by Fish et al. ${ }^{5}$ on unirradiated reference cladding tubes (Fig. 4 ). At the high ramp rates, the results for $20 \%$ cold-worked Type 316 stainless steel were in good agreement, but at $10^{\circ} \mathrm{F} / \mathrm{sec}$, our values of stable strain are substantially greater than those of Fish et al., possibly because of end effects in their tests. (Their samples were 2.45 in. long.) Their results on irradiated tubing tested at high ramp rates yielded values of stable strain much lower than those of unirradiated tubing (Fig. 4). It was thought that P-1 tubing might simulate the behavior of irradiated material, because our earlier tests (Figs. 6 and 7) with $40 \%$ cold-worked material had resulted in a much reduced ductility at 550 and $650^{\circ} \mathrm{C}$. However, a comparison of the data of Table III with Fig. 4 (even allowing for the thinner cladding wall) shows that the $38 \%$ cold-worked tubing undergoes rapid recovery at high heating rates, which results in enhanced ductility. In fact, a closer approximation of the reduced ductility exhibited by irradiated tubing is afforded by the $50 \%$ cold-worked tubing after aging.

The departure of $\mathrm{P}-1$ behavior from expectations is under investigation. Microhardness measurements on sections of as-received 20, 38, and $50 \%$ cold-worked tubing have verified that the $20 \%$ cold-worked material was softer. Thus, the possibility that $\mathrm{P}-1$ actually contained less cold work than the $20 \%$ cold-worked material appears unlikely. The microstructures and the fabrication history are being investigated to explain the behavior of $\mathrm{P}-1$. Furthermore, the possibility cannot be ruled out that the effect of wall thickness is greater than was anticipated on the basis of a simple load-area computation. This possibility is supported by the results of the initial tests on $20 \%$ cold-worked reference cladding tubes, with the wall thickness reduced from 15 to 10 mils by machining the outside diameter on a lathe (Table II). The resultant strains from $200^{\circ} \mathrm{F} / \mathrm{sec}$ tests on the thinned samples were much greater than those obtained by Fish et al. (Fig. 4) on 20\% cold-worked, 15-milwall tubes burst-test at the same load per unit area and with the same heating rate. 
Any ultimate explanation based on the wall thickness must accommodate the evident exaggeration of the thickness effect by high degrees of cold work. (Compare the machined sample results with those of P-1, unaged, in Tables I and II.) Burst tests of thinned, 50\% cold-worked tubing are planned. In addition, details of burst dynamics will be obtained photographically to determine whether rapid-forming phenomena are involved in the thin-wall burst behavior and to provide improved predictions of the high-temperature failure behavior of the simulant materials.

\section{Characterization of Simulated Ducts}

To date, characterization work on actual duct sections has been confined to room-temperature hardness and tensile tests. A section of duct removed after the first rough draw was obtained from Clark and Wheeler, the fabricators of FFTF ducts. The material had $\gtrsim 50 \%$ cold work and a $0.130-$ in. wall thickness. To compare this material with the final prototypic $20 \%$ coldwork duct, tensile specimens were cut from the duct flats and tested at strain rates of $0.02-1.0 \mathrm{~min}^{-1}$. Type 316 stainless steel specimens from heat V87210 were prepared by rolling solution-annealed material to 50 and $60 \%$ reductions in area without intermediate anneals. All tensile specimens had a 1.00-in.-long gauge section. The width and thickness of the gauge section were nominally 0.25 and $0.12 \mathrm{in}$. for the $20 \%$ cold-worked specimens, 0.25 and $0.15 \mathrm{in}$. for the $50 \%$ cold-worked specimens, and 0.25 and 0.06 or 0.07 in. for the $60 \%$ coldworked specimens. Smaller-gauge cross sections were used for specimens cold-worked $>20 \%$ to ensure a maximum specimen load below $10,0001 \mathrm{~b}$, the limit of the Instron load cell. However, the width-to-thickness ratio of all specimens was within the $8: 1$ range, where ductility comparisons are unaffected by variations in gauge width and thickness between specimens. The tensile axis of the test specimens was parallel to the longitudinal axis of the duct.

The room-temperature tensile results are summarized in Table V. Typical room-temperature stress-strain curves are shown in Figs. 9 and 10. The plastic strain (Eng.) at maximum and final loads, for tests terminated before specimen fracture, was measured on the test specimen in the absence of load. Specimen elastic strain (Eng.) was determined by the difference be tween the indicated total strain and the measured plastic strain. The indicated strains include some machine-compliance error. Thus, these data are used to compute yield stress and ultimate-tensile-strength (UTS) values rather than elastic moduli.

As indicated in Table V, Type 316 stainless steel exhibits $>2 \%$ uniform plastic strain after $60 \%$ cold work. Likewise, in Type 316 stainless steel, $50 \%$ cold work by extrusion produces a lower tensile strength and higher uniform plastic strain (UTS $\approx 147 \mathrm{ksi}, \mathrm{e}_{\mathrm{u}} \approx 3.6 \%$, where $\mathrm{e}_{\mathrm{u}}$ is engineering strain at maximum load) than $50 \%$ cold work by rolling (UTS $\approx 160 \mathrm{ksi}, \mathrm{e}_{\mathrm{u}} \approx 2.8 \%$ ). The lower uniform strain values shown for $50 \%$ cold-worked Type 316 stainless steel in Fig. 6 are attributed to the fact that the test specimens had a longer gauge length (2.0 in.) and a higher width-to-thickness ratio (8.3:1). 
TABLE V. Strength and Ductility of Cold-worked Type 316 Stainless Steel Duct Material at Room Temperature $\left(21^{\circ} \mathrm{C}\right)$

\begin{tabular}{|c|c|c|c|c|c|c|c|c|c|c|c|c|c|c|c|c|c|c|c|c|}
\hline \multirow{3}{*}{$\begin{array}{l}\text { Specimen } \\
\text { Number }\end{array}$} & \multirow{3}{*}{$\begin{array}{l}\% \text { Cold } \\
\text { Work }\end{array}$} & \multirow{3}{*}{$\begin{array}{c}\text { Average } \\
\text { Specimen } \\
\text { Cross-section } \\
\text { Area, } \\
10^{-2} \text { in. }^{2}\end{array}$} & \multirow{3}{*}{$\begin{array}{l}\text { Strain } \\
\text { Rate, } \\
\text { in./min }\end{array}$} & \multirow{3}{*}{$\begin{array}{c}0.2 \% \\
\text { Yield } \\
\text { Stress, } \\
\text { ksi }\end{array}$} & \multirow{3}{*}{$\begin{array}{l}\text { Width-to- } \\
\text { Thickness } \\
\text { Ratio }\end{array}$} & \multicolumn{3}{|c|}{ Tensile Strength, a ksi } & \multicolumn{4}{|c|}{ Uniform Strain, \% } & \multirow{2}{*}{\multicolumn{2}{|c|}{$\begin{array}{c}\text { Area } \\
\text { Reduction } \\
\text { at Maximum } \\
\text { Load, \% } \\
\end{array}$}} & \multirow{3}{*}{$\begin{array}{c}\text { Final } \\
\text { Engineering } \\
\text { Strain, }{ }^{a} \% \\
\varepsilon_{f}=e_{p}+e_{e}\end{array}$} & \multirow{2}{*}{\multicolumn{2}{|c|}{$\begin{array}{c}\text { Area } \\
\text { Reduction } \\
\text { at Final } \\
\text { Load, \% } \\
\end{array}$}} & \multirow{3}{*}{$\begin{array}{c}\text { Sample } \\
\text { Pulled } \\
\text { to } \\
\text { Failure } \\
\end{array}$} & \multirow{3}{*}{$\begin{array}{l}\text { Test } \\
\text { Date }\end{array}$} & \multirow{3}{*}{$\begin{array}{l}\text { Ratio }^{\mathrm{a}} \\
\varepsilon_{\mathrm{u}} / \varepsilon_{\mathrm{f}}\end{array}$} \\
\hline & & & & & & \multirow{2}{*}{$\begin{array}{l}\text { Eng. } \\
S=P / A_{0}\end{array}$} & \multicolumn{2}{|c|}{ True } & \multicolumn{2}{|c|}{ Eng. } & \multicolumn{2}{|c|}{ True } & & & & & & & & \\
\hline & & & & & & & $S(I+e)$ & $P / A_{i}$ & Plastic & Total & Plastic & Total & Eng. & True & & Eng. & True & & & \\
\hline 1 & $20^{\mathrm{b}}$ & 3.105 & 0.05 & 115.3 & 2.1 & 120.2 & 132.9 & 138.1 & 9.91 & 10.52 & 9.45 & 10.00 & 14.91 & 16.14 & 19.21 & 47.99 & 63.37 & No & $2-13-74$ & 0.55 \\
\hline 2 & $20^{b}$ & 3.010 & 0.05 & 116.3 & 2.1 & 123.8 & 134.9 & 138.9 & 8.35 & 8.97 & 8.02 & 8.59 & 10.89 & 11.54 & 17.96 & 42.49 & 55.32 & No & $3-22-74$ & 0.50 \\
\hline 3 & $20^{b}$ & 3.081 & 1.00 & 115.3 & 2.0 & 128.2 & 140.0 & 139.6 & 8.61 & 9.24 & 8.26 & 8.84 & 8.18 & 8.53 & 16.42 & 41.92 & 54.34 & No & $3-22-74$ & 0.56 \\
\hline 1 & $50 \mathrm{~b}$ & 2.268 & 0.05 & 143.2 & 1.0 & 147.4 & 153.7 & 151.8 & 3.53 & 4.25 & 3.47 & 4.16 & 3.57 & 3.64 & 15.50 & $>64.0$ & $>100.0$ & Yes & $2-12-74$ & 0.27 \\
\hline 2 & $50^{\mathrm{b}}$ & 2.273 & 0.50 & 143.8 & 1.0 & 147.3 & 155.2 & 154.4 & 4.63 & 5.35 & 4.53 & 5.21 & 4.84 & 4.96 & 12.69 & 52.00 & 73.41 & No & $2-12-74$ & 0.42 \\
\hline 3 & $50^{b}$ & 2.269 & 0.02 & 139.1 & 1.0 & 144.9 & 151.1 & 149.6 & 3.60 & 4.31 & 3.54 & 4.22 & 3.70 & 3.77 & 13.75 & 60.92 & 93.50 & No & $2-12-74$ & 0.31 \\
\hline 4 & $50 \mathrm{C}$ & 1.903 & 0.05 & 155.6 & 3.3 & 160.8 & 166.6 & 164.6 & 2.82 & 3.60 & 2.78 & 3.54 & 2.63 & 2.66 & 7.62 & 18.83 & 20.86 & No & $3-22-74$ & 0.47 \\
\hline 1 & $60^{C}$ & 1.519 & 0.02 & 150.0 & 4.2 & 167.9 & 172.2 & 172.5 & 2.59 & 3.36 & 2.56 & 3.30 & 2.76 & 2.74 & 9.22 & 31.77 & 38.23 & Yes & $3-22-74$ & C.36 \\
\hline 2 & $60 \mathrm{C}$ & 1.520 & 0.50 & 169.6 & 4.2 & 171.5 & 178.6 & 177.4 & 3.32 & 4.15 & 3.27 & 4.07 & 3.55 & 3.62 & 12.23 & 32.07 & 38.68 & Yes & $3-22-74$ & 0.34 \\
\hline 3 & $60 C$ & 1.506 & 0.05 & 165.1 & 4.2 & 170.1 & 175.8 & 173.7 & 2.55 & 3.37 & 2.52 & 3.31 & 2.52 & 2.56 & 6.71 & 17.41 & 19.13 & No & $3-22-74$ & 0.50 \\
\hline
\end{tabular}

as = engineering tensile strength; $P=$ load on sample; $A_{0}=$ original area; $e=$ engineering strain; $A_{i}=$ instantaneous area; $\varepsilon_{f}=$ true strain at failure; $e_{p}=$ plastic engineering strain; $e_{e}=$ elastic engineering strain; $\varepsilon_{\mathrm{U}}=$ maximum uniform true strain.

bcold work introduced by extruding.

ccold work introduced by rolling. 


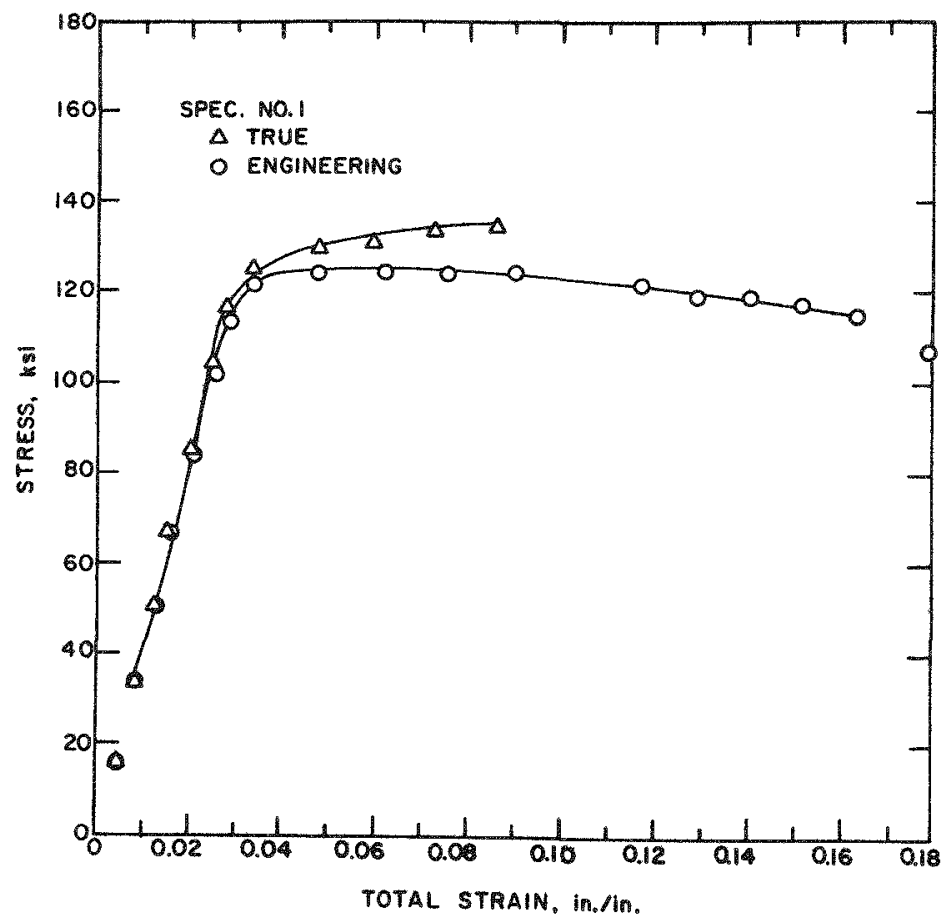

Fig. 9

Plot of True and Engineering StressStrain Behavior of $20 \%$ Cold-worked Type 316 Stainless Steel Extruded Duct. Neg. No. MSD-60312.

Fig. 10

Plot of True and Engineering Stress-Strain Behavior of $50 \%$ Cold-worked Type 316 Stainless Steel Extruded Duct. Neg. No. MSD-59894.

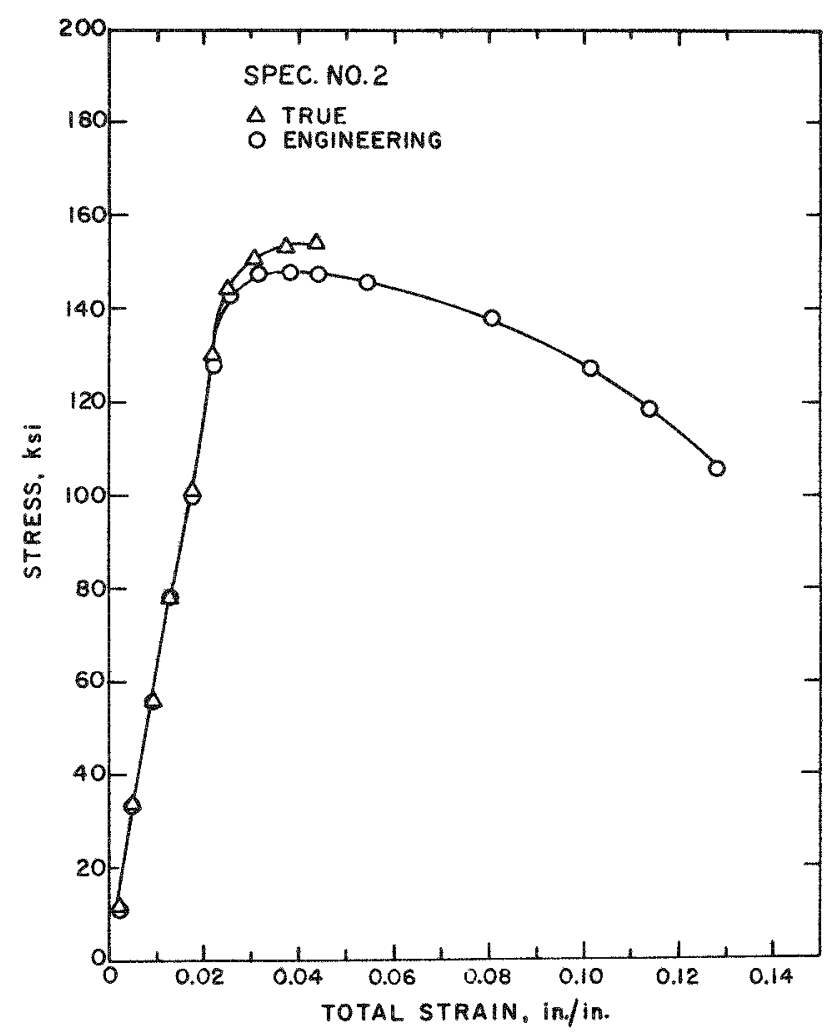

\section{Cladding-corrosion Effects}

The wastage due to fission-product attack represents by far the greatest corrosion of Type 316 stainless steel. Emphasis was therefore placed on evaluating the effect of corrosion of the cladding inside wall on its mechanical properties. 
a. Mechanical Properties. Corrosion of austenitic stainless steel cladding by fission products degrades the mechanical properties and contributes to the reduction in life of cladding alloys. An important reaction to consider in simulation experiments is the intergranular attack caused by cesium in combination with oxygen. A program in the Materials Science Division has been devoted to studying the effects of grain-boundary corrosion (penetration depth of $0-10$ mils) by cesium oxides on the tensile properties and biaxial creep-to-failure properties of $20 \%$ cold-worked Type 316 stainless steel (heat V87210) at temperatures between $550^{\circ} \mathrm{C}\left(1022^{\circ} \mathrm{F}\right)$ and $760^{\circ} \mathrm{C}\left(1400^{\circ} \mathrm{F}\right)$. Since this work has been reported in detail elsewhere, ${ }^{10,11}$ only the major conclusions are discussed here.

The tensile test specimens fabricated from the sheet material were exposed to cesium oxides at $660^{\circ} \mathrm{C}\left(1220^{\circ} \mathrm{F}\right)$ for up to $100 \mathrm{hr}$ to produce various grain-boundary-penetration depths. The tensile properties of the specimens were determined at several temperatures and strain rates between 0.4 and $0.004 \mathrm{~min}^{-1}$. The grain-boundary penetration reduces both the loadcarrying capacity of the material and the ductility, as measured by the elongation and reduction in cross-sectional area. The degradation in strength properties resulting from corrosion can be quantitatively explained by assuming that the penetration of the specimens by cesium oxides is equivalent to the reduction in cross-sectional area.

The effect of corrosion on cladding-failure stress was studied as part of the present program. The stress-to-failure properties of the tubular cladding specimens, with different grain-boundary-penetration depths and internally pressurized by helium, were investigated at various temperatures. The se data show that the time to failure, in all cases, and ductility (as measured by change in diameter), in most cases, decrease significantly with an increase in intergranular penetration depth.

The reduction in strength resulting from grain-boundary corrosion can be quantitatively explained by assuming that the effect of grainboundary penetration is equivalent to the reduction in the tube-wall thickness of the specimen (i.e., the inner diameter a, for specimens exposed to cesium oxides, becomes equal to $a+2 x$, where $x$ is the maximum depth of grainboundary penetration). This approach enables the failure times for the exposed specimens to be predicted from the unexposed specimen data within a factor of three or better (Fig. 11). In addition, the dependence of failure mode on stress, strain rate, temperature, and grain-boundary corrosion has been established. In particular, pinhole leaks predominate at elevated temperatures and/or at lower strain rates. For example, at $760^{\circ} \mathrm{C}\left(1400^{\circ} \mathrm{F}\right)$, the transition from pinhole to rupture occurs at strain rates of $\sim 10^{-3} \mathrm{hr}^{-1}$, and at $704^{\circ} \mathrm{C}\left(1299^{\circ} \mathrm{F}\right)$, the transition occurs at $2-4 \times 10^{-4} \mathrm{hr}^{-1}$, pinhole failure being dominant at lower strain rates. 


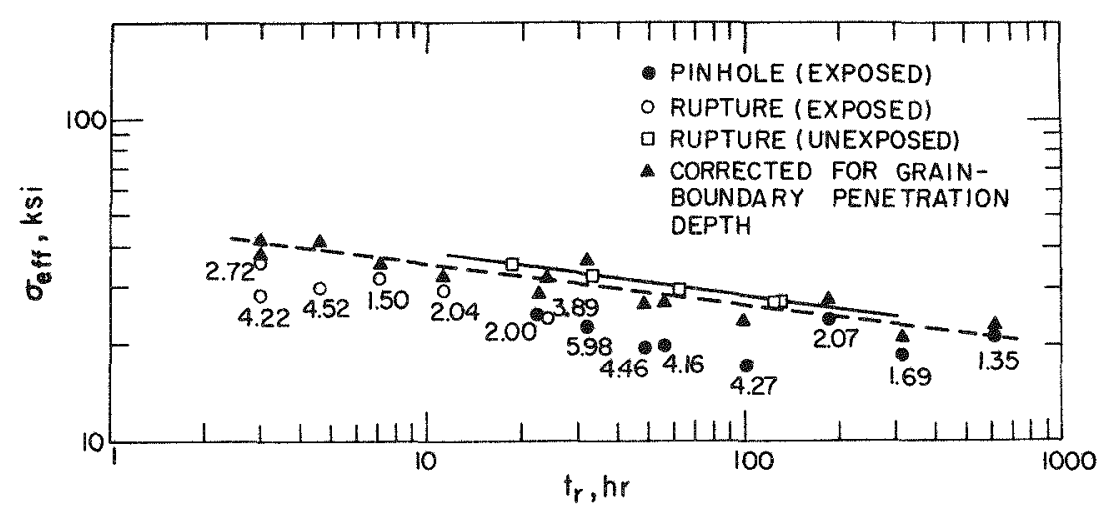

Fig. 11. Effect of Grain-boundary Penetration by Cesium Oxides on the Biaxial Stress-rupture Behavior of Type 316 Stainless Steel at $704^{\circ} \mathrm{C}$. Numbers indicate depth of penetration in mils. Neg. No. MSD-59209.

b. Cladding Wastage. The wastage equations shown below were used to predict wastage profiles in a 36-in.-long fuel element that operated at $12 \mathrm{~kW} / \mathrm{ft}$ for 320 full-power days to a burnup of $80,000 \mathrm{MWd} / \mathrm{MTM}$ (Fig. 12).

(1) HEDL Correlation ${ }^{3}$

$D=133 t^{0.63} \exp (-10,000 / T)$, where $D$ is the depth of the fuel-cladding reaction in mils, $t$ is time in hours, and $T$ is the cladding inside surface temperature in ${ }^{\circ} \mathrm{K}$.

(2) WARD Correlations 12

(a) Fuel-cladding Attack

$D=5.034 \times 10^{-3} \exp (-5185 / T) \cdot \operatorname{burnup}(M W d / M T M)$

(b) Sodium Reaction, $R$, in mils

$R=43,695.5 \exp (-12,765 / T) \cdot O \cdot t$, where $T$ is the cladding surface temperature or sodium temperature in ${ }^{\circ} \mathrm{K}, \mathrm{O}$ is the oxygen content in ppm, and $t$ is time in years. The equation is valid for velocities $>7 \mathrm{ft} / \mathrm{sec}$.

(c) Ferrite Layer Reaction, d, in mils

$d=\left(8.085 \times 10^{12}\right) / R^{\prime} \exp (-29,685 / T)$, where $T$ is the cladding surface temperature in ${ }^{\circ} K$, and $R^{\prime}$ is the sodium reaction rate $(R / t)$. The predicted wall-thickness reduction varies from $\sim 1.5 \mathrm{mils}$ at the top to $\$ 0.5 \mathrm{mil}$ at the midplane for the $482^{\circ} \mathrm{C}\left(900^{\circ} \mathrm{F}\right)$ outlet temperature and from $5.5 \mathrm{mils}$ at the top to $\sim 1.5 \mathrm{mils}$ at the midplane of the element for the $593^{\circ} \mathrm{C}$ $\left(1100^{\circ} \mathrm{F}\right)$ core-outlet temperature. Below the midplane, little if any attack occurs. These predictions can be compared with the recommended FFTF cladding wastage allowances for $10,000 \mathrm{hr}$ of operation, which are uniformly 7 and 8.6 mils for 482 and $593^{\circ} \mathrm{C}$ core-outlet temperatures, respectively. ${ }^{12}$ 


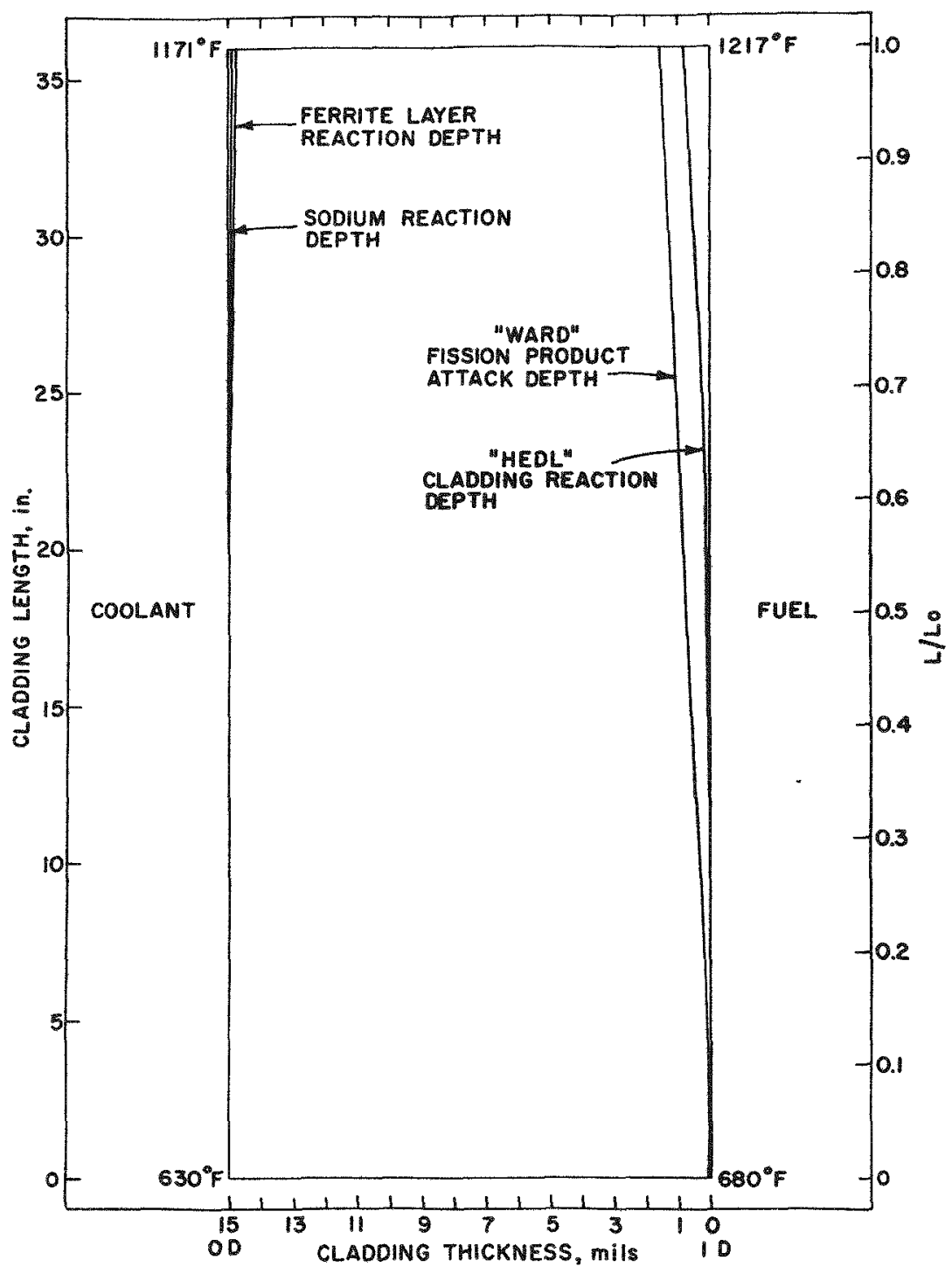

(a)

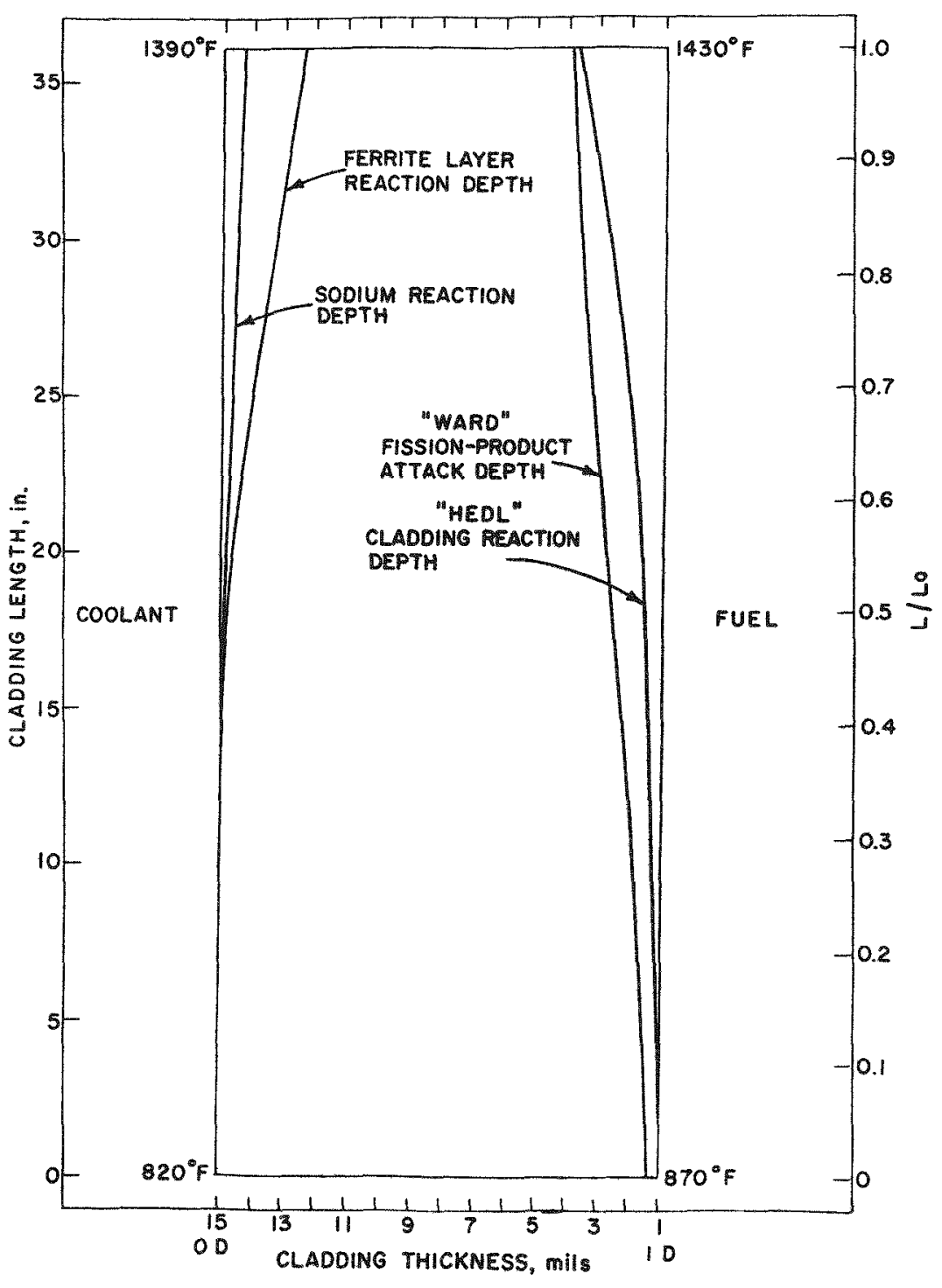

(b)

Fig. 12. Predicted Cladding Wastage in a 36-in.-long Fuel Element That Has Operated at $12 \mathrm{~kW} / \mathrm{ft}$ for 320 Full-power Days to a Burnup of $80,000 \mathrm{MWd} / \mathrm{MTM}$. (a) $900^{\circ} \mathrm{F}$ outlet temperature and (b) $1100^{\circ} \mathrm{F}$ outlet temperature. Neg. Nos. MSD -59837 and -59838 . 
Based on Fig. 12, a realistic EOL simulation of cladding should provide for an axially graded thickness profile with a minimum wall thickness at the top of the fueled section. This would necessitate the development of an internal preferential etching process.

\section{CONCLUSIONS}

We have emphasized the simulation of the mechanical response of irradiated cladding to rapid heating caused by loss of cooling. Under such conditions, our crude analysis of events indicates that the cladding will expand away from the fuel, and, for most situations, the element will respond as an internally gas-pressurized tube. Therefore, a first-order approximation of an irradiated fuel element is a suitably embrittled cladding containing fresh or slightly irradiated fuel that is in the correct structural condition (i.e., cracked or restructured by a few reactor cycles) and has a gas volume (pressure) appropriate to the burnup condition. The last two requirements can be met either during fabrication or during initial in-reactor conditioning. We must, however, begin with the embrittled cladding, and the planners of the SLSF P-1 test decided to use a heavily cold-worked (40\%) Type 316 stainless steel cladding. Thus, our initial experimental work has concentrated on evaluating the degree of embrittlement of Type 316 stainless steel by cold work. The following major facts have emerged.

1. A 50\% cold-worked, or 50\% cold-worked and aged, Type 316 stainless steel, 15-mil-wall cladding will fail after $<1 \%$ stable strain at $1150-$ $1260^{\circ} \mathrm{C}\left(\sim 2100-2300^{\circ} \mathrm{F}\right)$ when subjected to a $111^{\circ} \mathrm{C}\left(200^{\circ} \mathrm{F}\right) / \mathrm{sec}$ heating $\mathrm{ramp}$. Heating rates of $\sim 6^{\circ} \mathrm{C}\left(10^{\circ} \mathrm{F}\right) /$ sec resulted in increased ductility and raised the failure temperature to $1260-1282^{\circ} \mathrm{C}\left(2300-2340^{\circ} \mathrm{F}\right)$. This represented the best near-term simulated materials for SLSF experiments in the form of cladding and ducts.

2. The 38\% cold-worked, 10-mil-wall cladding chosen for the SLSF P-1 test annealed rapidly during transient heating. The ductility appeared to go through a minimum as the heating rate was increased from $\sim 6$ to $111^{\circ} \mathrm{C} / \mathrm{sec}$, but the maximum stable strains at failure were generally large and attained values of $\sim 23 \%$ (i.e., at least 20 times the strain observed in the irradiatedtube experiments by Fish et $a .^{5}$ ), although the failure-temperature ranges were the same. Cladding bulges of this magnitude during a transient could cause local contact of adjacent elements $\left(24 \% \Delta \mathrm{D} / \mathrm{D}\right.$ will cause local contact $\left.{ }^{4}\right)$; this could provide additional restriction of coolant flow and cladding overheating. A nonprototypic fuel-element failure sequence would result.

Aging reduces the bulging, but not to levels that would be prototypic in an in-reactor experiment. Since the P-1 elements have been fabricated, it will be necessary to account for this enhanced ductility in the pre- and posttest analyses of the P-1 test. Bulging problems could be avoided by 
depressurizing the elements. An alternative viewpoint is to operate the experiment as originally planned to determine the consequences of cladding bulging and flow blockage in the element bundles.

3. Additional study on diffusion treatments leading to nitrided or carburized Type 316 stainless steel is required, because the structures developed appear to be stable at high temperatures for long periods and could be used as simulated materials for lower ramp rates. For example, the first nitrided tube tested failed at $0.77 \%$ average stable strain during an $\sim 6^{\circ} \mathrm{F} / \mathrm{sec}$ heating ramp. Cold work anneals out partially under these conditions.

4. The simulation of fission-product corrosion effects on cladding mechanical properties appears to be straightforward. A simple correction for reduction in load-bearing area will account for the observed reduction in rupture strength. However, the consistency of the depth-of-attack data leaves much to be desired. The HEDL data imply a saturation effect with increasing burnup, whereas the WARD approach shows a linear dependence on burnup. Recent results obtained by Neimark ${ }^{13}$ support the former results, whereas the out-of-reactor simulation studies by Maiya and $\mathrm{Busch}^{14}$ show that the penetration depth is linear with time under isothermal conditions. However, despite the difference of opinion, it is clear that the P-1 tubing, reduced from a $15-$ to a 10-mil wall, represents a pessimistic prediction of cladding wastage. Inas much as the wall is uniformly thinned along the 36-in. length, a nonprototypic failure point might also occur. In future experiments, graded wall-thinning techniques must be developed to account for the axial differences in wall thinning (Fig. 12).

\section{ACKNOWLEDGMENT}

We wish to express our appreciation to B. E. Lepacek for his participation in the sample preparation and treatment and in the construction and operation of the experimental apparatus. 


\section{REFERENCES}

1. J. F. Schumar, E. W. Barts, J. C. Carter, R. J. Dunworth, R. O. Ivins, B. M. Hoglund, and R. E. Wilson, Fuel Element Failure Propagation Program Plan, ANL/MET-01 (Aug 1969).

2. Preliminary System Design Description of the Fuel Element Failure Propagation In-pile Loop System, ANL/RAS 71-40 (Dec 1971).

3. C. Cox, Hanford Engineering Development Laboratory, private communications (Aug 16, 1973, and Jan 28, 1974).

4. C. Hunter, Hanford Engineering Development Laboratory, private communications (Aug 16, 1973, and Apr 1974).

5. R. L. Fish, C. W. Hunter, and J. J. Holmes, Strain Response and Failure of 20\% Cold Worked Type 316 Stainless Steel Cladding during Temperature Transients, HEDL-TME 73-4, Vo1. 1 (May 1973).

6. J. J. Holmes, A. J. Lovel1, and R. L. Fish, Ductility of Irradiated Type 316 Stainless Steel, HEDL-SA 310 (June 1972).

7. E. E. Bloom and J. 0. Stiegler, Effect of Irradiation on the Microstructure and Creep-rupture Properties of Type 316 SS, Ann. ASTM Meet., June 1972, Los Angeles, Calif.

8. J. E. Spruie11, J. A. Scott, C. S. Ary, and R. L. Hardin, Met. Trans. 4, 1533 (1973).

9. B. Weiss and R. Stickler, Met. Trans. 3, 851 (1972).

10. F. Rosa and P. S. Maiya, J. Nuc1. Mater. 50, 111 (1974).

11. F. Rosa, P. S. Maiya, and R. W. Weeks, "Effect of Grain-boundary Penetration of AISI Type 316 Stainless Steel by Cesium Oxides on Elevatedtemperature Tensile Properties," Proc. Symp. Elevated Temperature Properties of Austenitic Stainless Steels, A. 0. Schaefer, ed., Metals Properties Council, Inc., ASME, New York, 1974, pp. 97-112.

12. D. C. Jacobs, Westinghouse Advanced Reactor Division, private communications (May 28, 1971, and Aug 1973).

13. L. A. Neimark, ANL, private communication (Apr 1974).

14. P. S. Maiya and D. E. Busch, Met. Trans. 4, 663 (1973). 